\title{
Information Asymmetry and Accounting Conservatism under IFRS Adoption
}

\author{
Xiaoting(Christy) Lu \\ Master of Science in Management \\ Studies in Accounting \\ Submitted in partial fulfillment \\ Of the requirements for the degree of \\ Master of Science
}

Faculty of Business, Brock University

St.Catharines, ON

(C) Xiaoting(Christy) Lu 2012 


\title{
Information asymmetry and Accounting Conservatism under IFRS Adoption
}

\begin{abstract}
LaFond and Watts (2008) provide evidence that information asymmetry might be a determinant of accounting conservatism. One implication of their paper is that regulators trying to reduce information asymmetry by lowering the level of accounting conservatism might be wrong. However, there is a trend in moving away from conservative accounting. The typical example is IFRS adoption. Therefore, this paper studies information asymmetry and accounting conservatism under IFRS adoption. The results show that the level of accounting conservatism decreases after mandatory IFRS adoption, but the adoption of IFRS is likely to weaken the relationship between information asymmetry and accounting conservatism. Moreover, this paper investigates how the change of accounting conservatism under IFRS is related to the change in information environment. The finding shows that accounting conservatism increases information environment, supporting the idea that, by providing comparatively credible information, conservative accounting is beneficial to the information environment.
\end{abstract}

Keywords: information asymmetry; accounting conservatism; IFRS. 


\section{Table of Contents}

Pages

Abstract $\quad$ ii

List of Tables $\quad$ iv

List of Figures $\quad$ iv

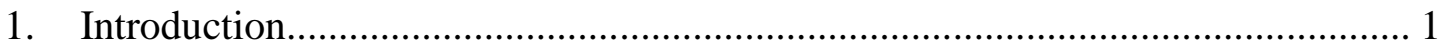

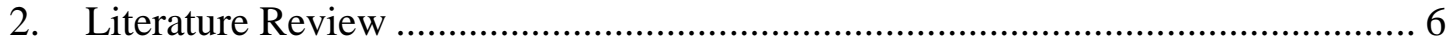

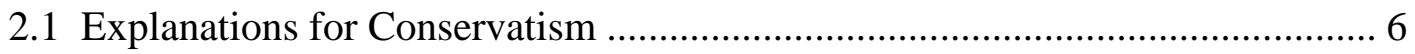

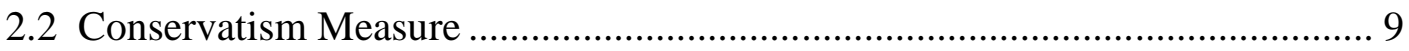

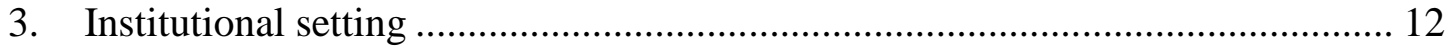

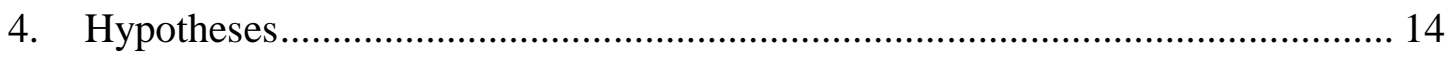

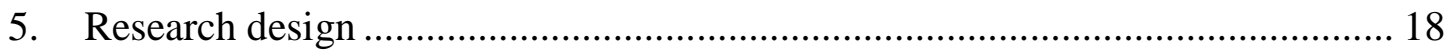

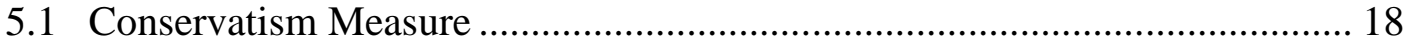

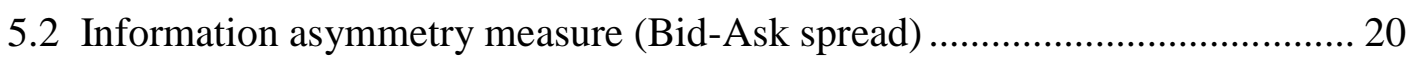

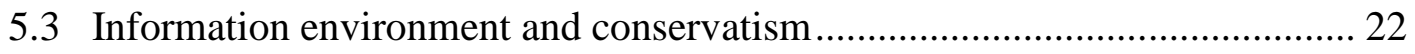

6. Sample Selection and Descriptive Statistics ................................................... 22

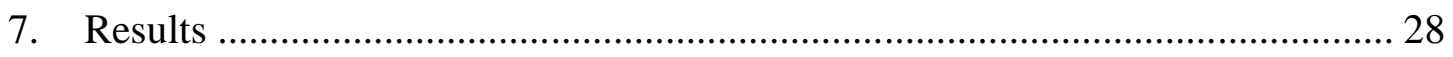

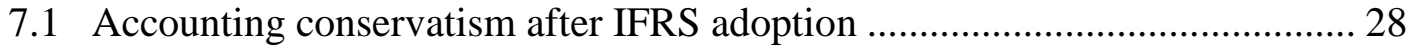

7.2 Accounting conservatism and Information asymmetry ............................. 37

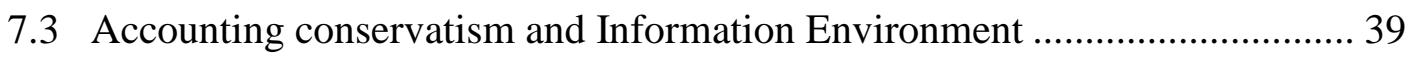

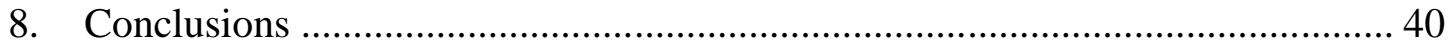

References $\quad 41$ 


\section{List of Tables}

Pages

Table 1: Sample firms breakdown according to country and IFRS adoption timing . 23

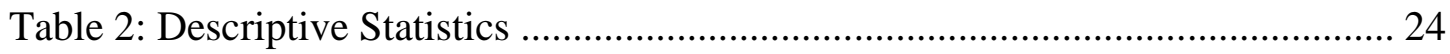

Table 3: Correlation Matrix (Pearson Top; Spearman Bottom) ............................... 27

Table 4: Mean Coefficients from Estimation Regression of Equation (1) and (3) ..... 29

Table 5: Coefficients from Basu (1997) regressions by high, medium, and low

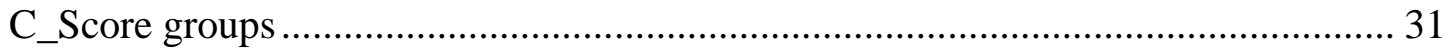

Table 6: Comparison of C_Score and Basu Coefficient per year (pooled) ................ 32

Table 7: Coefficients of Basu (1997) model across year (pooled) ............................ 34

Table 8: Basu coefficients for Early, On-time, and Late IFRS adopters .................... 36

Table 9: Mean Coefficients from Estimation Regression of Equation (4) and (5) ..... 37

Table 10: Mean Coefficients from Estimation Regression of Equation (6) ............... 39

\section{List of Figures}

Pages

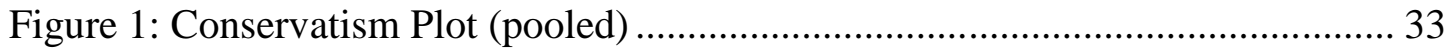

Figure 2: Good news versus Bad news Plot (pooled) ............................................ 35

Figure 3: Conservatism Plot of Early, On-time, and Late IFRS adopters ................. 37 


\section{Introduction}

Conservatism is a traditional measure of the profits by recording the losses immediately and the gains after the realization. Basu (1997) interprets conservatism as accountants' tendency to require a higher degree of verification to recognize good news as gains than to recognize bad news as losses. The long term result of accounting conservatism is an understatement of net assets. LaFond and Watts (2008) have shown the relationship between information asymmetry and accounting conservatism. The primary research objective of my paper is to extend LaFond and Watts (2008) study by investigating the change in the level of conservatism after mandatory IFRS adoption, and the effect of IFRS on this relationship. There is also an argument mentioned by LaFond and Watts that conservative accounting is beneficial to the information environment. However, this was not been tested. Therefore, the second research objective of this paper is to examine the relationship between accounting conservatism and information environment.

Conservatism exists in financial reports (Dechow et al., 1999; Beaver and Ryan, 2000; Basu, 1997; Givoly and Hayn, 2000). Researchers have proposed four explanations for conservative accounting: contracting, litigation, regulation, and taxation (Watts and Zimmerman, 1986; Ball, 1989; Basu, 1997; Watts, 2003). Recently, LaFond and Watts (2008) investigate the relationship between information asymmetry and conservatism. Their study sheds lights on the view that information asymmetry might be another important determinant of conservatism. They also provide evidence that the effect of information asymmetry on conservatism exists after controlling for contracting and litigation effects. This implies that the effect of information asymmetry on conservatism cannot be attributed to other potential sources of conservatism. If there are no correlated omitted variables in their tests, one crucial implication of their paper is that the aim of accounting standard setters trying to reduce information asymmetry by lowering the level of accounting conservatism in financial statements might not by be achieved. However, there is a trend in financial reporting standards which is moving away from conservative accounting to fair value accounting. The most typical example is the wide adoption of IFRS around the world. 
According to the IFRS website, there are approximately 120 nations and reporting jurisdictions which permit or require IFRS for domestic listed companies. In the literature, to date, most papers focused on documenting the change of economic consequences of IFRS adoption, such as cost of capital, comparability, and accounting relevance. However, few papers have investigated the level of information asymmetry after IFRS adoption and there is even fewer empirical evidences investigating the change in conservatism after IFRS adoption. Therefore, in order to fill up this gap in the literature, my paper investigates information asymmetry and accounting conservatism under IFRS adoption.

In LaFond and Watts (2008) paper, they also argue that conservative financial reports are likely to generate a more informed capital market than financial reports that include more unverifiable information. However, what constitutes an informed capital market has not been carefully defined and, also, this implication is not tested in their paper. Hu and Zhang (2011) extend LaFond and Watts (2008) by using Basu (1997) model to capture accounting conservatism and firm-specific return volatility to proxy for informed capital market. Their paper mainly focuses on informativeness of stock price. They calculate their measure of firm-specific return volatility using data based on an expanded market model given in Jin and Myers (2006). Finally, they document that information environment is positively associated with accounting conservatism in their international dataset. I define an informed capital market as an analyst information environment which is different from $\mathrm{Hu}$ and Zhang (2011). In the prior literature, numerous studies use the characteristics of analyst forecasts as a proxy for the information environment (Lang and Lundholm, 1996; Gebhardt et al., 2001; Lang et al., 2003). Consistent with them, I am able to investigate the relationship between accounting conservatism and information environment. After mandatory IFRS adoption, which provides a good setting to examine this research issue, firms are more flexible in choosing accounting methods than before, because IFRS was supposed to reduce accounting discretion and improve uniformity. Related parties, such as debt-holders, shareholders, and analysts might change their attitudes towards accounting numbers presented in financial statements and, thus, alter the requirement for conservatism. For example, after IFRS adoption, if debt-holders 
anticipate that the accounting numbers become less credible, they will set up more stringent requirements in debt contracts, such as higher net asset, to compensate for the loss in accounting credibility. If this is the case, then, the capital market after mandatory IFRS adoption is actually less informed.

Different from mandatory IFRS adoption firms (on-time or late IFRS adopters) which are expected to be more conservative in accounting before, early IFRS adopters might not experience a significant change in the relationship between conservatism and information asymmetry. There are two reasons. First, even though these firms are standing outside of main stream in the economy before mandatory adoption, they are leaders in the industry after mandatory IFRS adoption with an established accounting record of IFRS numbers. Analysts can directly evaluate accounting numbers of these firms. However, mandatory adoption firms still need more time to fully understand IFRS and get used to reporting under IFRS. This might hinder analysts' evaluation referring to accounting numbers. Second, early IFRS adopters have already fully taken the benefits and costs into consideration before voluntarily adopting IFRS, and, thus, the conservatism of early adoption firms might not change during the IFRS transition period. Consequently, even though the mandatory IFRS adoption might exert influence on conservatism, the level of accounting conservatism of early adoption firms is expected to be remained the same.

I focus on a sample of European countries which required mandatory adoption of IFRS after 2005. The goal of IFRS is to improve financial reporting internationally, increase the comparability, reducing information asymmetry and reduce cost of capital. To some level, the standard-setters are trying to reduce information asymmetry between firms and outside investors by incorporating more unverified value into financial reports. However, since conservatism is a simple response to the change of information asymmetry (LaFond and Watts, 2008), trying to reduce information asymmetry through lowering conservatism might not be effective. Nevertheless, there are papers indirectly documenting a lower level of information asymmetry after mandatory IFRS adoption (Ashbaugh and Pincus, 2001; Wang et al., 2007; Daske et al., 2008; Armstrong et al., 2010; Li, 2010). These studies do not 
violate the findings of LaFond and Watts (2008), because firms still can benefit from IFRS adoption from other sources, such as higher comparability which will lower information asymmetry. In my paper, in order to focus only on the role of conservatism, I investigate the effect of mandatory IFRS adoption on the relationship between information asymmetry and conservatism. In addition, I also expect European countries mandatorily adopting IFRS after 2005 to be a worthwhile setting to investigate, because this is a significant change in IFRS adoption history. Moreover, the extant empirical literature investigating the economic consequences after mandatory IFRS adoption is unclear. Further, the mandatory IFRS adoption setting provides an explicit cutoff date, using which I can separate the data and analyze the situation before and after IFRS adoption.

Following Basu (1997), I use the asymmetric timeliness of gain and loss recognition to measure accounting conservatism. Following Lang et al. (2003), I use the characteristics of analyst forecasts as a proxy for the information environment. Specifically, I consider how forecast accuracy and analyst following during the period around the mandatory adoption of IFRS in Europe. I assess the robustness of my results by using C_Score (Khan and Watts, 2009). It is a measure of accounting conservatism at the firm-year level. Also, I provide evidence that this measure is valid in European countries setting, because it can effectively distinguish firms with different level of conservatism.

My study contributes to the existing literature in several ways. First, despite the large literature on accounting conservatism, few studies have investigated the effect of IFRS on relationship between information asymmetry and conservatism. Using Basu coefficients, LaFond and Watts (2008) find that information asymmetry is positively associated with conservatism and, also, it is information asymmetry leads to conservatism. Piot et al. (2010) examine the change of conditional conservatism after IFRS adoption. They find that conditional conservatism, as measured by the asymmetric timeliness of bad vs. good news, has decreased under IFRS, notably among Big 4 audits. Unlike those studies, my paper concentrates on the effect of IFRS on the relationship between information asymmetry and conservatism. This 
means I provide a new view by taking information asymmetry, conservatism and IFRS into consideration simultaneously.

Second, this paper makes contribution to the literature on analyst's information environment after IFRS adoption. Horton and Serafeim (2010) examine the effect of mandatory IFRS on firms' information environment and find that the improvement is limited to non-financial firms that mandatorily adopt IFRS. My paper further studies the impact of conservatism on analyst's information environment after IFRS adoption, expanding and shedding lights on literature by linking conservatism which is an important feature of accounting information to analyst's information environment.

Third, my paper also contributes to the literature on economic consequences of IFRS adoption. In prior literature, the effect of IFRS adoption is mixed. On one hand, researchers find that there is a decrease in information asymmetry and cost of capital after IFRS adoption. Daske et al. (2008) document a decrease in firms' cost of capital and an increase in equity valuation in countries with strong legal enforcement. Li (2010) finds a decrease in cost of capital in mandatory IFRS adoption case. However, on the other hand, Soderstrom and Sun (2007) argues that cross-country differences in accounting quality are likely to remain following IFRS adoption. My paper investigates effect of IFRS on information asymmetry and conservatism, adding evidence on economic consequences of IFRS adoption.

Finally, this paper also has important regulatory implication to countries concerning mandatory IFRS adoption. LaFond and Watts (2008) argue that more conservative accounting is likely to generate more informed capital market. IFRS, which incorporates more fair value into financial statement, contradicts their argument. This paper examines the effect of conservatism on information environment after IFRS adoption, which has significant implication to standardsetters and countries considering IFRS adoption. 


\section{Literature Review}

Conservatism's influence on accounting practice has been long and significant (Watts, 2003). Although there is a trend in moving from conservative accounting to fair value accounting, conservatism still cannot be eliminated. The survival of conservatism suggests that it has its own benefits. If regulators and standard-setters ignore its benefits and try to eliminate conservatism without fully understanding these benefits, the resultant standards are likely to damage the role of accounting as an information source (Khan and Watts, 2009).

\subsection{Explanations for Conservatism}

In the literature, there are four traditional alternate explanations for conservatism: contracting, litigation, taxation, and accounting regulation. There are also several non-conservatism explanations for asymmetric timeliness or asymmetric earnings response coefficients, such as financial options (Dhaliwa et al., 1991; Fischer and Verrecchia, 1997; Core and Schrand, 1999; Plummer and Tse, 1999), adaptation option (Burgstahler and Dichev, 1997), real option (Christophe, 2002), earnings management (Hanna, 2002) and abandonment option (Hayn, 1995), that provide some level of evidence on conservatism, but cannot be the major explanations (Watts, 2003).

Contracting is an early explanation for conservatism. Its arguments are fully developed. Under the contracting explanation, conservative accounting is used as a tool to mitigate the moral hazard problem generated by asymmetric information, asymmetric payoffs, limited horizons and limited liability. Firms enter into many contracts. Two particularly important contracts are debt contracts between the firm and its debt-holders and executive compensation contracts between the firm and its managers. From the debt contracts perspective, debt-holders are more concerned on verifiable lower bound of the current value of net assets because the potential unverifiable gains of net assets do not add additional benefits. However, if the firm cannot guarantee enough net assets to cover the payments to debtholders, because of limited liability, lenders might have to receive less than promised. Therefore, debt- 
holders demand verifiable loss recognition to assure the minimum amount of net assets exceeds the dollar amounts of debt contracts. Nikolaev (2010) uses a sample of over 5,000 debt issues and finds evidence that reliance on covenants in public debt contracts is positively related with the degree of timely loss recognition. Beatty et al., (2008) also document a positive relationship between debt contract and the degree of timely loss recognition. This indicates that debtholders would prefer to use covenants to protect their own benefits under conservative accounting.

From compensation contracts perspective, managers have incentives to introduce bias and noise to accounting measures, because compensation package is partially based on accounting numbers. Conservatism constrains managerial opportunistic behavior and managerial biases with timely loss recognition and delaying gain recognition. On one hand, in order to maximize their benefits, managers are motivated to release information of potential gains in the future. On the other hand, conservatism assures the disclosure of losses which managers would like to hide. Basu(1997), Ball and Shivakumar (2005, 2006) and Kothari et al. (2005) explicitly address the role of accruals in asymmetrically timely loss recognition. In both debt contracts and compensation contracts, conservatism is regarded as an efficient corporate governance mechanism to mitigate agency costs by providing timely loss signals. Debtholders and shareholders can use conservative accounting to protect their benefits. Consequently, contracting is one of the explanations of conservatism in financial reports.

Litigation explanation asserts that, since firms are more likely to be sued if they overstate net assets than understate net assets (Kellogg, 1984; St. Pierre and Anderson, 1984), management and auditors have incentives to report conservative earnings and net asset values. Taxation explanation indicates that delaying the recognition of revenue and accelerating the recognition of expense enable managers of profitable firms to reduce taxes and increase the value of firm. Therefore, they have incentives to adopt conservative accounting. Similar to the taxation explanation, regulation explanation claims that regulators might face more criticism if firms overstate net 
assets than if they understate net assets. Thus, in order to reduce political costs, standard-setters and regulators demand unconditional conservatism.

The above four factors (Watts, 2003a) that drive conservatism can be viewed as four sources of demands for accounting conservatism. Empirical evidences on the relation between conservatism and contracting and litigation explanations are more frequent in the literature. There are limited studies that illustrate the taxation and regulation explanations. Using the Basu (1997) regression model, Francis and Martin (2010) find that the positive association between timely loss recognition and acquisition profitability is more pronounced for firms with higher agency costs. Park and Wynn (2008) also provide evidence. This is consistent with contracting explanation. LaFond and Roychowdhury (2008) provide evidence that financial reporting conservatism is one potential mechanism to address agency problems between managers and shareholders, which imply economic demand for conservatism. By classifying conservatism into conditional and unconditional, Qiang (2007) directly test the four factors and finds that contracting only induces conditional conservatism; taxation and regulation only induces unconditional conservatism; litigation induces both. Drawing on sample of Spanish firms, Cano-Rodriguez (2010) concludes that large accounting firms promote conditional conservatism, thereby increasing the contracting efficiency of their clients' accounting information. His study indicates that large accounting firms also demand for conservative accounting.

More recently, LaFond and Watts (2008) provide evidence that information asymmetry generates conservatism. Since contracting explanation is somewhat related to information asymmetry, they control the impact of contracting and litigation explanations to find a significant association. This means information asymmetry captures something other than traditional sources of conservatism, shedding lights on new determinants of conservative accounting. They also highlight the long existence of conservatism. However, empirical studies testing information asymmetry as a source of conservatism is limited. The only exception is LaFond and Watts (2008) using U.S. data. One of the important implications of LaFond and Watts (2008) paper is that if the regulates ignore this causal relationship, their attempt to 
decrease information asymmetry by lowering the level of conservatism, incorporating more unverifiable value in financial reports might not be achieved. IFRS adoption is a typical example of moving away from conservative accounting, aiming at reducing information asymmetry which is opposite to LaFond and Watts predicted relationship. Therefore, I expect the IFRS adoption will induce a corresponding change in the level of conservatism and exert influence on the relationship between information asymmetry and conservatism. My paper will add value to the literature from this point of view.

\subsection{Conservatism Measure}

A number of measures of conservatism have been used in the conservatism literature. Wang et al. (2009) summarize five key measures of accounting conservatism. They are Basu's (1997) asymmetric timeliness of earnings measure, Ball and Shivakumar's (2005) asymmetric-cash-flow-to-accruals measure, the Market-to-Book ratio, Penman and Zhang's (2002) hidden-reserves measure, and Givoly and Hayn's (2000) negative-accruals measure.

Basu coefficient is the most widely used measure of accounting conservatism in the prior literature (Ryan, 2006; Wang et al., 2009). Wang et al. (2009) test the validity of five measures mentioned above under a construct validity perspective, addressing the question of inconsistency among these measures. They present a survey reviewing papers which adopt measures of conservatism that have been widely applied and have been published in journals through to May 2009. The frequency table in their paper shows that Basu coefficient measure is by far the most frequently used measure for conservatism in the literature. Because of the extensive use of Basu coefficient, there are also plenty of critics towards it. Ryan (2006) point out that bad news as losses might not be reflected in earnings in a timely manner because of buffer problems in GAAP. Watts (2003) argues that certain economic events which are unrelated to conservatism will generate asymmetric timeliness of gain and loss recognition. Hanna (2003) identified several types of discretionary accounting behavior which might also affect asymmetric timeliness of gain and loss recognition. Givoly et al., (2006) argues that there is a little time-series consistency in estimates of 
asymmetric timeliness at the firm level. Despite of limitations, Ryan (2006) still argues that Basu coefficient is the most direct implication of conditional conservatism in asymmetric timeliness, comparing it with the measures suggested by Dietrich et al. (2007).

$\mathrm{M} / \mathrm{B}$ ratio and negative accruals measure are the second and third used measure of accounting conservatism. Although Dietrich et al. (2007) suggest using them instead of Basu coefficient, which contains bias, to capture conservatism, Ryan (2006) strongly argues against their view and point out that these two measures are assessing the overall conservatism instead of conditional conservatism. Moreover, these measures are likely to be driven by unconditional conservatism. Therefore, they are likely not useful for measuring conditional conservatism unless the effect of conditional and unconditional conservatism can be separated. However, a key advantage of using $\mathrm{M} / \mathrm{B}$ ratio to measure conservatism is that this measure is strongly rooted in the analytical work based on Residual Income Valuation Model (Feltham and Ohlson, 1995), which is one of the valuation models only under extremely simplistic and unrealistic assumptions in the accounting literature (Lo and Lys, 2002; Callen and Morel, 2002). But, using M/B ratio might have confounding problems, because it is also a well-known proxy for many factors other than accounting conservatism in accounting and finance literature, such as it is used to proxy for default risk in finance literature and growth in accounting literature, which is identical to conservatism in the Ohlson model.

Roychowdhury and Watts (2007) compare Basu coefficient and M/B ratio as measures of conservatism and investigate the relationship between these two proxies to address the question on the validity of asymmetric timeliness as an empirical measure of conservatism. An important basis for the question is the observed negative correlation between the Basu measure and $\mathrm{M} / \mathrm{B}$ ratio. There are major two explanations for the negative correlation. First, theoretically, the benchmark for conservatism is separable net assets and changes in separable net assets by rents and changes in growth option. However, $\mathrm{M} / \mathrm{B}$ and Basu coefficient assume this benchmark as equity value and changes in equity value. Thus, both M/B and the Basu 
coefficient measures of conservatism have errors. Second, they argue that the negative relationship is due to time horizons used in empirical research. When using short time horizon, Basu coefficient might fail to recognize gains that increase $\mathrm{M} / \mathrm{B}$ and serve as a buffer problem. Nevertheless, Roychowdhury and Watts (2007) paper also asserts that the Basu coefficient is a better measure of conservatism because any noise introduced by growth options changes should be mitigate over long horizons (Basu, 1997; Pope and Walker, 1999; Ball et al., 2000). In summary, despite of critics, the Basu coefficient remained as the major measure of conditional conservatism.

However, one disadvantage of Basu coefficient is that it cannot make firmspecific measurements. In particular, the Basu (1997) coefficient has to be estimated either on an annual basis using a cross-section of observations or on a firm-specific basis using time-series observations. Both estimation methods have limitations. The former method assumes all firms in the industry are homogeneous and the latter method assumes that the firm's operating characteristics are stationary. Khan and Watts (2009) develop a conservatism measure, C_Score, based on Basu (1997) regression model, incorporating firm-specific characteristics. C_Score can reflect the timing of conservatism changes and the variation of conservatism across firms within an industry.

C_Score has several advantages. First, it can reflect both time- and firmspecific changes affecting firm's financial reporting conservatism, such as a change in the information asymmetry caused by a firm-specific reduction in growth opportunities (LaFond and Watts, 2008). Second, it can be estimated for firms that only have positive returns, which the Basu coefficient cannot. This implies using C_Score can enlarge sample size in conservatism studies. Third, introducing three firm-specific variables, it captures the four explanations- contracting, litigation, taxation and regulation- that drive conservatism as a whole. Although C_Score has advantages stated before, it has not been widely used to measure conservatism so far. Therefore, this paper uses both Basu coefficients as major test and C_Score for robust check the main hypothesis. 


\section{Institutional setting}

International Financial Report Standards (IFRS) will likely eventually be adopted by countries all around the world. According to the IFRS website, approximately 120 nations and reporting jurisdictions permit or require IFRS for domestic listed companies. Although 90 countries have fully conformed to IFRS and include a statement acknowledging such conformity in audit reports, some other countries including Korea is expected to transition to IFRS by 2011; Mexico will require IFRS for all listed companies in 2012; Japan has been considering the adoption of IFRS. ${ }^{1}$ United States is also considering a timeline of transition to IFRS for firms that want to start reporting under IFRS. In recent years, IASB has continued to take steps to extend the application of IFRS adoption.

The European Union required publicly listed companies to present consolidated financial statements consistent with IFRS for each financial year starting after 1 January 2005 (EC Regulation No. 1606/2002). While mandatory IFRS adoption is required after 2005, there are still exemptions. For example, Swiss firms that are not multinationals are exempt from IFRS reporting. These companies may continue to use Swiss GAAP, or they can choose between IFRS or US GAAP (Deloitte, 2008). These firms which are not reporting under IFRS are excluded in my study. Firms that are reporting under IFRS can be divided into two groups. Voluntary adopters include all firms that adopted IFRS before 2005, while mandatory adopters include firms forced by EU to adopt IFRS.

The economic consequences after mandatory IFRS adoption are still unclear. Standard-setters claim that the adoption of IFRS has the ability to reduce the information asymmetry, increase comparability, and, thus, decrease cost of capital by providing comparatively more reliable estimation about future cash flows, making financial statement more useful to investors. Daske et al. (2008) report an increase in earnings quality for a sample of firms that voluntarily adopt IFRS. Li (2010) provides

\footnotetext{
${ }^{1}$ IFRS FAQ. (n.d.) How widespread is the adoption of IFRS around the world. Retrieved December 16, 2010, from http://www.ifrs.com/ifrs faqs.html\#q3.
} 
evidence that the significant drop in cost of capital still exists under mandatory IFRS adoption. Armstrong et al. (2010) document an incrementally positive reaction for firms with lower pre-adoption information and with higher pre-adoption information asymmetry. Ashbaugh and Pincus (2001) consider IFRS as a high quality set of standards providing valuable information to investors. Wang et al. (2007) examine the effect of mandatory IFRS adoption, and find that there is a significant decrease in earnings forecast errors. Another argument in favor of mandatory IFRS adoption is that the global movement towards IFRS creates a set of worldwide accounting standards, making it easier for foreign investors interpreting firms' financial statements and, thus, lowering related cost (Andre and Filip, 2012).

However, there are also plenty of criticisms towards the mandatory adoption of IFRS, which is considered as a set of fair-value oriented and comprehensive accounting standards than most local GAAP in Europe. Ries and Stocken (2007) as well as Dye and Sunder (2001) find that even though the informativeness of a report using fair value completely reveals a firm's inventory holdings, difficulties of implementing fair value measurements hamper this ability. Moreover, the financial crisis in 2008 sounded the alarm to standard setters and has led to a vigorous debate about the pros and cons of fair value accounting. Khan (2010) finds that fair value reporting is associated with an increase in systemic risk ${ }^{2}$ in banking industry. In addition, LaFond and Watts (2008) argue for a causation relationship between information asymmetry and conservatism. They argue that standard-setters who are trying to reduce information asymmetry and increase transparency by incorporating more unverifiable values might not achieve their goal. Consequently, mandating the use of IFRS may not make financial reports more comparable or more informative, suggesting that the economic consequences of mandatory IFRS adoption can be small or negligible. As different views stated above, the capital market reaction towards mandatory IFRS adoption remains as an important empirical issue.

\footnotetext{
${ }^{2}$ Systemic risk is the risk or probability of breakdowns in an entire system, as opposed to breakdowns in individual parts or components (Kaufman and Scott, 2000).
} 


\section{Hypotheses}

It is unclear how accounting conservatism will change after the mandatory adoption of IFRS, which is a allegedly principle-based accounting method. It is possible that conservatism will decrease if, for example, investors expect higher financial reporting quality than original domestic standards after mandatory adoption of IFRS, thereby enhancing financial reporting transparency, reducing information asymmetry and information risk and, thus, lowering cost of capital. Accounting conservatism will decrease since information asymmetry and conservatism is positively associated (LaFond and Watts, 2008). This prediction is supported by prior research. For example, Armstrong et.al (2010) finds that investors react positively to firms with lower pre-adoption information quality, especially to banks when they adopt IFRS. Their findings are consistent with view that mandatory adoption of IFRS will mitigate information asymmetry. Similarly, Brochet et.al (2011) finds that private information reduces following IFRS adoption because of the increases in comparability. Daske et al. (2008) also provide early evidence on economic consequences after mandatory IFRS adoption. They document, on average, a decrease in firms' cost of capital and an increase in equity valuation in countries where firms have incentives to be transparent and where legal enforcement is strong. Using Basu coefficients, Piots et al. (2010) finds that conditional conservatism has decreased under IFRS, particularly among Big 4 audit firms.

However, it is also possible that accounting conservatism may increase after mandatory IFRS adoption if, for example, investors expect accounting numbers to be less verifiable. The credibility which is the most important characteristics of accounting playing as a role of information source comparing with other information sources, such as press or media, decreases. Therefore, investors will require higher rate of return, enhancing cost of capital. In addition, information asymmetry will increase if investors anticipate more earnings management. IFRS are principle-based standards with minimal implementation guidance. After the adoption of IFRS, firms are more flexible in choosing accounting estimates methods and, thus, it is reasonable for investors to anticipate that managers will prefer accounting methods giving them 
more room to manage earnings. If this is the case, then, from managers' perspective, they have incentives to make the reported financial statement seem credible by choosing conservative accounting methods and, thus, enhance conservatism. LaFond and Watts (2008) argue that incorporating more fair value into financial statements, such as an increase in growth options, will generate an increase in information asymmetry and accounting conservatism. Ahmed et al. (2010) conclude that mandatory IFRS adoption will lower accounting quality, resulting in smoother earnings, more aggressive reporting of accruals, and a reduction in timeliness of loss recognition relative to gain recognition. Despite of concentrating on only three countries, namely Australia, France and UK, Jeanjean and Stolowy (2008) find that earnings management did not decline after IFRS adoption and even increased in France. Examining earnings management and timely loss recognition, Christensen et al. (2009) finds that accounting quality improvement after IFRS adoption are confined to firms with incentives to adopt and concludes that incentives are the most essential element on accounting standards in determining accounting quality. This indicates the change of earnings quality under mandatory IFRS adoption is still unclear. Accordingly, we hypothesize the following:

H1: The accounting conservatism changes after mandatory IFRS adoption.

I test this hypothesis in two parts:

H1a: The accounting conservatism increases after mandatory IFRS adoption.

H1b: The accounting conservatism decreases after mandatory IFRS adoption.

Mandatory IFRS adoption is a regulatory change in accounting standards. In hypothesis H1, I expect a change in conservatism after mandatory IFRS adoption, no matter increases or decreases. The next question is what drives this change of conservatism. One possible reason is that parties closely related to or using accounting numbers might respond correspondently to this change and, therefore, generate a change in their demands for accounting conservatism. There are four traditional explanations, contracting, litigation, taxation, and regulation, which are mentioned before as a whole, because there is reason to believe that these four factors 
are not independent (Watts, 2003b). Moreover, on the base of Basu coefficient, C_Score adds three more variables-M/B, size and leverage-that are widely available and commonly used as proxies for the firm's investment opportunity set (IOS) which lead to the change of four factors.

Another possible reason that might explain the change of conservatism after mandatory IFRS adoption is the change in information asymmetry. LaFond and Watts (2008) argue that information asymmetry between firm insiders and outside investors generates conservatism in financial statements. This implies that information asymmetry might be another determinant of conservatism. Generally speaking, more unverifiable current value of future cash flow will be estimated and shown in the financial statements (Piot et al., 2010). For example, IFRS requires the recognition of in-house intangible assets, while it remains optional under continental national GAAP. The more unverifiable items are included, the higher level of information asymmetry between managers and outside investors. If this is the case, then, the change of accounting conservatism after IFRS adoption might be the result of change in information asymmetry. Further, LaFond and Watts (2008) document a positive relationship between information asymmetry and conservatism. Consequently, I hypothesize the following:

H2: The change of accounting conservatism after IFRS adoption is positively related to the change in information asymmetry.

If I find information asymmetry is the significantly driver for the change in conservatism after mandatory IFRS adoption, then, what is the specific effect of IFRS on the relationship between information asymmetry and conservatism? On one hand, mandatory IFRS adoption might strengthen the relationship between them. IFRS, which is a principle-based accounting standard, require firms to incorporate more fair value into financial statements, especially the change in goodwill, research and development expenses (R\&D), and asset revaluation (Aharony et al., 2010). This suggests that accounting number will be less reliable, because of recognizing more unverifiable gains. Also, more opportunistic earnings management will be expected. Given this case, debt-holders, share holders, and auditors are more eager for 
conservative accounting. Therefore, in this sense, mandatory adoption of IFRS strengthens the association between information asymmetry and conservatism. However, it is also possible that the relationship is weakened by IFRS adoption, because related parties might turn to other information sources for help, such as increasing option-based compensation and decreasing earnings-based compensation. Accordingly, I hypothesize the following:

H3a: The IFRS adoption strengthens the relationship between information asymmetry and conservatism.

H3b: The IFRS adoption weakens the relationship between information asymmetry and conservatism.

LaFond and Watts (2008) argue that conservative financial reports are likely to generate a more informed capital market than financial reports that include unverifiable information. This means accounting conservatism is positively related with the information environment. Although accounting cannot reduce information asymmetry by providing more unverified information, conservative accounting still can benefit the information environment between equity investors through other ways. On one hand, conservative accounting provides hard information on firms' current performance. High verification criteria of gains and low verification criteria of losses is likely to limit manager's tendency of overstating unverifiable gains and understating losses, making the gains and losses presented in financial statements credible. Thus, conservative accounting can facilitate the flow of information and result in a better information environment. On the other hand, conservative accounting serves as a bench-mark for other information sources. If there is potential gains affecting future cash flow but are not allowed to be recorded in financial statement according to accounting standards, managers have incentives to release those good news through other information sources, such as manager comments or press release. Conservative accounting can discipline other sources of information (Watts, 2006). Equity investors can compare other sources of information to the conservative financial statement information, evaluating information reliably. Thus, 
as a bench-mark, conservative accounting may result in a better information environment.

IFRS adoption, which is moving away from conservative accounting, indicates lowering the verification criteria of gains, incorporating more unverifiable information in financial statements, and, thus, making accounting information more unreliable. Since I expect a change in the level of conservatism after mandatory IFRS adoption, there might associate a change of information environment in European countries in the same direction. Consequently, I hypothesize the following:

H4: The conservatism is positively related to firms' information environment under IFRS adoption.

\section{Research design}

\subsection{Conservatism Measure}

First, I run Basu(1997) model to get Basu coefficients on pooled data and, then, on three groups of firms separated by by IFRS adoption timing- early, on-time, and late.

Second, I use C_Score (Khan and Watts, 2009) to proxy accounting conservatism. Empirical evidence related to application of C_Score is limited. Khan and Watts (2009) demonstrate the validity of C_Score by using U.S. data. Lai and Taylor (2008) provide evidence that conservatism, measured by C_Score, is a pervasive attribute of financial reporting under Australian GAAP. Specifically, I first estimate C_Score for each firm per year by using the following equation:

$$
\begin{gathered}
X_{i, t} / P_{i, t-1}=\beta_{0}+\beta_{1} D_{i, t}+R_{i, t}\left(\mu_{0}+\mu_{1} \text { Size }_{i, t}+\mu_{2} M / B_{i, t}+\mu_{3} \operatorname{Lev}_{i, t}\right)+ \\
D_{i, t} R_{i, t}\left(\lambda_{0}+\lambda_{1} \text { Size }_{i, t}+\lambda_{2} M / B_{i, t}+\lambda_{3} L_{L v_{i, t}}\right)+\left(\delta_{1} \text { Size }_{i, t}+\delta_{2} M / B_{i, t}+\right. \\
\left.\delta_{3} \operatorname{Lev}_{i, t}+\delta_{4} D_{i} \text { Size }_{i, t}+\delta_{5} D_{i, t} M / B_{i, t}+\delta_{6} D_{i, t} L_{e v_{i, t}}\right)+\varepsilon_{i, t}
\end{gathered}
$$

where $\mathrm{X}$ is earnings per share; $\mathrm{P}$ is year-end stock price per share; $\mathrm{R}$ is the return on firm I from 9 months before fiscal year-end t to 3 months after fiscal year-end t, total 12-month return; $\mathrm{D}$ is a dummy variable that equals 1 if $\mathrm{R}$ is negative and 0 
otherwise; Size is the natural logarithm of market value of equity at the end of year; $\mathrm{M} / \mathrm{B}$ is market-to-book ratio; Lev is leverage ratio that is defined as the sum of shortterm and long-term debt divided by market value of equity at the end of year. FamaMacBeth regression estimates Equation (1), yielding $\lambda_{0}$ to $\lambda_{3}$. Then, I can calculate C_Score for each firm-year as Equation (2)

$$
C_{-} \text {Score }_{i, t}=\lambda_{0}+\lambda_{1} \text { Size }_{i, t}+\lambda_{2} M / B_{i, t}+\lambda_{4} \operatorname{Lev}_{i, t}
$$

where Size is the natural logarithm of market value of equity; M/B is market-to-book ratio; Lev is leverage ratio, defined as the sum of short-term and long-term debt divided by market value of equity. Four factors that drive conservatism vary with firm's investment opportunity set (IOS). Therefore, instead of measuring the individual effects of the four factors, Khan and Watts (2009) use three firm-specific variables- size, M/B and leverage- to capture variation in IOS which vary with four factors. In my study, I consider all the four factors as a whole.

In Equation (1), the coefficients $\lambda_{0}, \lambda_{1}, \lambda_{2}, \lambda_{3}$ are used to calculate C_Score in Equation (2). Then, I average the C_Score for each year and plot them to see the moving trend of the level of accounting conservatism after mandatory IFRS adoption. According to Hypothesis 1, I expected a change after 2005, which means the accounting conservatism is affected by the adoption of IFRS. However, the direction is unknown. It may increase (H1a) or decrease (H1b).

One thing might be noticed is that C_Score is motivated from the four determinants (contracts, litigation, taxation, regulation) of conservatism in the U.S. Khan and Watts (2009) caution that it might not be an appropriate conservatism measure in studies using data from countries where the institutional features differ from U.S. institutional features in important ways, such as countries with a weak legal enforcement regime. To address this concern, I plan to examine whether C_Score can effectively distinguish firms with different levels of conservatism consistent with other commonly used conservatism measure, basically the Basu (1997) coefficients. In addition, Givoly et al. (2007) examine the power and reliability of the Basu coefficient. They identify three certain characteristics of the information environment 
unrelated to conservatism that affect the Basu coefficient. They are aggregation effect, nature of the economic events effect, and disclosure policy effect. Thus, they suggest that we can't rely on any single measure to assess the overall conservatism (Gigler and Hemmer, 2001). This is also the reason that my paper includes two different measures of conservatism---the Basu coefficient, and C_Score, even though C_Score is developed from the Basu model.

I estimate the Basu (1997) regression again on the pooled data but with three

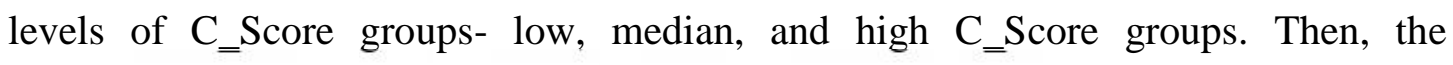
following regression is estimated for each group.

$$
X_{i, t} / P_{i, t-1}=\beta_{0}+\beta_{1} D_{i, t}+\beta_{2} R_{i, t}+\beta_{3} D_{i, t} R_{i, t}+\varepsilon_{i, t}
$$

where $\mathrm{X} / \mathrm{P}$ is earnings scaled by lagged price; $\mathrm{R}$ is the return on firm I from 9 months before fiscal year-end t to 3 months after fiscal year-end t, total 12-month return on; $\mathrm{D}$ is a dummy variable equal to 1 if returns are negative, and 0 elsewhere. $\beta_{2}$ refers to the Basu coefficients for good news. $\beta_{3}$ measures the level of conservatism. If I figure out that the Basu coefficients from the regression increase with C_Score groups, I can conclude that the C_Score measure is effective in distinguishing between firms in European countries with different levels of conservatism based on the Basu conservatism measure. In my paper, I will only calculate the Basu coefficients under fiscal period returns. Despite Basu tests a number of other specifications in his paper, all of them come up with similar results. Therefore, I will only compare C_Score with the Basu coefficients under fiscal period returns. One thing worth to notice when using Basu coefficients is the buffer problem which causes the annual Basu coefficients to understate the degree of conservatism. However, the buffer problem can be released by using long horizon to estimate asymmetric timeliness (Basu, 1997).

\subsection{Information asymmetry measure (Bid-Ask spread)}

I use bid-ask spread to test the changes of information asymmetry after mandatory adoption of IFRS. In accounting prior literature, bid-ask spread is a commonly used proxy for information asymmetry (Welker, 1995; Healy et al., 1999; 
Leuz et al., 2000; Daske et al., 2008). It measures the information asymmetry between inside and outside investors in trading markets. I obtain the daily closing bid and ask prices for each day from IBES and compute the daily spread as the difference between bid price and ask price. The bid-ask spread for a firm-year is the average of the daily spreads for that firm-year and, then, scaled by the midpoint of the spread.

Hypotheses 2 investigate the positive relationship between information asymmetry and accounting conservatism. I test the hypotheses by following equation:

$$
\begin{aligned}
& X_{i, t} / P_{i, t-1}=\beta_{0}+\beta_{1} D_{i, t}+\beta_{2} R_{i, t}+\beta_{3} D_{i, t} R_{i, t}+\beta_{4} B_{i d} / A s k_{i, t}+\beta_{5} B_{i d} / A s k_{i, t} D_{i, t} \\
& +\beta_{6} \text { Bid } / A s k_{i, t} R_{i, t}+\beta_{7} \text { Bid } / A s k_{i, t} D_{i, t} R_{i, t}+\varepsilon_{i, t}
\end{aligned}
$$

where Size, M/B, and Lev as defined before; Bid/Ask represents the level of information asymmetry after mandatory IFRS adoption. Coefficient $\beta_{7}$ is expected to be positive, because the information asymmetry and conservatism change in the same direction (LaFond and Watts, 2008).

I test the effect of IFRS on the relationship between information asymmetry and conservatism (H3) by following regression.

$$
\begin{aligned}
& X_{i, t} / P_{i, t-1}= \\
& \beta_{0}+\beta_{1} D_{i, t}+\beta_{2} R_{i, t}+\beta_{3} D_{i, t} R_{i, t}+\beta_{4} B i d / A s k_{i, t}+\beta_{5} B i d / A s k_{i, t} D_{i, t}+
\end{aligned}
$$

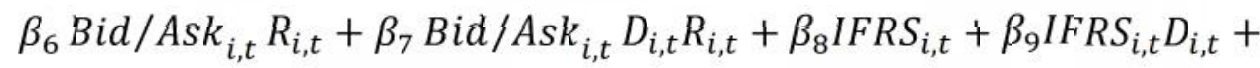

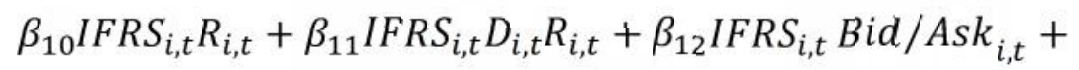

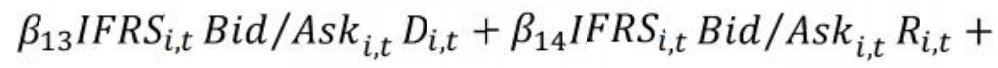

$$
\begin{aligned}
& \beta_{15} I_{F R S} B_{i, t} \text { Bid } / A s k_{i, t} D_{i, t} R_{i, t}+\varepsilon_{i, t}
\end{aligned}
$$

where $\mathrm{X} / \mathrm{P}$ is earnings scaled by lagged price; $\mathrm{R}$ is the 12-month fiscal return on firm $\mathrm{i}$; $\mathrm{D}$ is a dummy variable equal to 1 if returns are negative, and 0 elsewhere; Bid/Ask represents the level of information asymmetry after mandatory IFRS adoption. According to Hypothesis 3 , the sign of coefficient $\beta_{15}$ can be positive (H3a) or negative (H3b). 


\subsection{Information environment and conservatism}

Prior research by Gebhardt et al. (2001) and Lang et al. (2003) uses the characteristics of analyst forecasts as a proxy for the information environment. Houston et al. (2006) provide evidence that greater coverage by analysts is negatively related to information asymmetry between firms and investors. Consequently, it has been used to proxy for a firm's information environment. Consistent with prior literature, I also use analyst variables- the accuracy of analyst forecasts and the number of analysts following the firm, as indicative of changes in a firm's information environment.

To investigate the effect of conservatism on information environment, I test the differences in analyst variables before and after mandatory IFRS adoption in 2005 for all firms. Consequently, I generate the following equation:

$$
\mathrm{IE}_{\mathrm{i}, \mathrm{t}}=\gamma_{1}+\gamma_{2} \mathrm{C} \_ \text {Score }_{\mathrm{i}, \mathrm{t}}+\sum_{\mathrm{j}}^{\mathrm{N}} \gamma_{\mathrm{j}} \text { controls }+\varepsilon_{\mathrm{i}, \mathrm{t}}
$$

where $\mathrm{IE}_{\mathrm{i}, \mathrm{t}}$ is either forecast error, analyst following or volatility of revisions for firm $\mathrm{i}$ and time period t. Following Horton and Serafeim (2010), forecast error is the absolute error deflated by the closing stock price of the previous year (Cheong and Thomas, 2011). Analyst following is the number of analysts forecasting earnings per share for a firm. C_Score is defined as before and calculated from Equation (2). Controls are control variables suggested by previous literature, including market value, forecast horizon, earnings surprise, and market return. If the coefficient $\gamma_{2}$ is significant and positive, information environment and conservatism is positively correlated, indicating more conservative accounting is associated with a higher level of information environment.

\section{Sample Selection and Descriptive Statistics}

I request publicly listed companies geographically located in one of the European community countries in the WorldScope database. This initial query yielded 6,171 firms. The accounting and stock return data are from Worldscope and Datastream. Analysts' forecast data are from IBES. I delete firms whose accounting 
standards are unknown, firms who are non-IFRS adopters until 2010, firms with negative market-to-book ratio, and also firms with missing data of the major variables to test accounting conservatism. The final sample includes 1,954 firms from 19 countries $^{3}$. The test time period ranges from 2001 to 2010, covering both the preIFRS period and post-IFRS period. I group the sample firms according to countries and IFRS adoption timing. Table 1 summarizes the results.

Table 1: Sample firms breakdown according to country and IFRS adoption timing

\begin{tabular}{lcccc}
\hline Country & $\mathbf{N}$ & Early $(\boldsymbol{\%})$ & On-time (\%) & Late (\%) \\
\hline AT: Austria & 39 & $\mathbf{1 3 . 9 9}$ & 0.81 & 0.38 \\
BE: Belgium & 65 & 5.7 & 3.80 & 1.33 \\
CZ: Czech Republic & 6 & 1.55 & 0.24 & 0 \\
DE: Germany & 272 & $\mathbf{5 8 . 5 5}$ & 9.87 & 7.03 \\
DK: Denmark & 88 & 4.66 & 4.61 & 4.18 \\
ES: Spain & 78 & 0.52 & 6.07 & 0.38 \\
FI: Finland & 71 & 3.63 & 4.85 & 0.76 \\
FR: France & 315 & 1.04 & $\mathbf{2 0 . 0 6}$ & $\mathbf{1 2 . 3 6}$ \\
GB: United Kingdom & 529 & 0.52 & $\mathbf{1 4 . 8 9}$ & $\mathbf{6 5 . 0 4}$ \\
GR: Greece & 95 & 0.52 & 7.44 & 0.38 \\
HU: Hungary & 12 & 3.63 & 0.32 & 0.19 \\
IE: Ireland & 29 & 0 & 1.46 & 2.09 \\
IT: Italy & 111 & 0 & 8.09 & 2.09 \\
LU: Luxembourg & 10 & 2.07 & 0.40 & 0.19 \\
NL: Netherlands & 76 & 1.55 & 5.50 & 0.95 \\
PL: Poland & 21 & 0.52 & 1.54 & 0.19 \\
PT: Portugal & 31 & 0.52 & 2.35 & 0.19 \\
SE: Sweden & 106 & 0.52 & 7.69 & 1.90 \\
SK: Slovakia & 1 & 0.52 & 0 & 0 \\
\hline Total & $\mathbf{1 9 5 4}$ & 100 & 100 & 100 \\
\hline
\end{tabular}

Table 1 shows sample firm breakdown according to country and IFRS adoption timing. The full sample contains 1954 firms from 19 European countries. Firms adopting IFRS before 2005 are regarded as early adopters; firms adopting IFRS in 2005 are regarded as on-time adopters; firms adopting IFRS after 2005 are regarded as late adopters.

\footnotetext{
${ }^{3}$ The 19 countries in this study include Austria, Belgium, Czech Republic, Germany, Denmark, Spain, Finland, France, United Kingdom, Greece, Hungary, Ireland, Italy, Luxembourg, Netherlands, Poland, Portugal, Sweden, and Slovakia.
} 
Table 1 shows different IFRS adoption patterns across the European countries included in this paper. Early adopters refer to firms adopting IFRS before 2005; ontime adopters are regarded as firms adopting IFRS in 2005; late adopters are firms adopting IFRS after 2005. Consist with prior studies (e.g., Daske et al. 2008; Piot et al. 2010), more than $50 \%$ of IFRS early adopters are Germany firms. Austria firms ranks second. Conversely, France and United Kingdom seem to simply follow the requirement. About 35\% of on-time adopters are France and United Kingdom firms. In addition, over $75 \%$ of late adopters are from France and United Kingdom. Overall, the majority firms in my sample are from United Kingdom, France, Germany, Italy, and Sweden. They cover approximately $70 \%$ of 1,954 firms.

Table 2: Descriptive Statistics

\begin{tabular}{|c|c|c|c|c|c|c|c|}
\hline & Mean & $\underline{\text { StdDev }}$ & Q1 & Median & $\underline{\text { Q3 }}$ & $\underline{\text { Min }}$ & Max \\
\hline \multicolumn{8}{|c|}{ Variables used in calculating Basu coefficient and C_Score } \\
\hline Earnings-Price ratio & 0.037 & 0.485 & 0.003 & 0.031 & 0.078 & -0.186 & 0.124 \\
\hline Return & 0.078 & 0.493 & -0.173 & 0.057 & 0.267 & -0.964 & 0.340 \\
\hline Size & 13.737 & 2.836 & 11.600 & 13.500 & 15.700 & 5.050 & 23.34 \\
\hline $\mathrm{M} / \mathrm{B}$ & 2.980 & 2.713 & 2.060 & 2.477 & 4.925 & 0.003 & 9.678 \\
\hline Lev & 1.086 & 3.439 & 0.054 & 0.239 & 0.852 & 0.002 & 4.349 \\
\hline \multicolumn{8}{|c|}{ Variables used in information environment model } \\
\hline Forecast error & 0.243 & 2.648 & 0.005 & 0.014 & 0.045 & 0.000 & 11.35 \\
\hline Analyst following & 50.220 & 59.781 & 9 & 29 & 71 & 1 & 555 \\
\hline Forecast horizon & 5.271 & 0.422 & 5.176 & 5.258 & 5.398 & -2.511 & 6.345 \\
\hline Earnings surprise & 0.032 & 0.520 & -0.013 & 0.001 & 0.028 & -1.547 & 1.511 \\
\hline
\end{tabular}

Table 2 shows descriptive statistics for 19,540 firm-years between 2001 and 2010. The mean, standard deviation (StdDev), median and first (Q1) and third (Q3) quartiles are reported. Earnings-Price ratio is calculated as earnings per share (Worldscope item \#05201) divided by price (Worldscope item \#05001). Return is the return on each firm from 9 months before fiscal year-end to three months after fiscal year-end, including dividend paid and adjusted for stock dividens and capital contributions (Datastream). Size is the natural $\log$ of market value of equity. Market value of equity is calculated as common shares outstanding (Worldscope item \#05301) times price (Worldscope item 
\#05001). M/B stands for the market-to-book ratio of common equity based on the closing price at year end. Lev is leverage, defined as short-term debt (Worldscope item \#03051) and long-term debt (Worldscope item \#03251) divided by market value of equity calculated before.

Forecast error is the absolute error divided by the closing stock price of the previous year. Analyst following is the natural log of the number of analysts forecasting earnings per share for a firm. Forecast horizon is defined as the natural log of the number of days between the forecast's issue date and the earnings announcement date. Earnings surprise is defined as the change in earnings per share between two years divided by the closing stock price of the previous year.

Table 2 summarizes descriptive statistics of main variables required to calculate C_Score for the full sample and test analyst information environment. The mean, standard deviation, median, first and third quartiles as well as minimum and maximum numbers are reported. Earnings-Price ratio is calculated as earnings per share divided by price per share. Mean (median) Earnings-Price ratios are 0.037 (0.031). Return is defined as the return on each firm from 9 months before fiscal yearend to three months after fiscal year-end, including dividend paid and adjusted for stock dividends and capital contributions. Mean (median) returns are 0.078 (0.057). Size is the natural log of market value of equity. Mean (median) sizes are 13.737 (13.500). Market-to-Book ratio is calculated as market value of equity divided by common equity. Mean (median) Market-to-Book ratios are 2.980 (2.477). Lev is defined as short-term debt and long-term debt divided by market value of equity. Mean (median) leverages are 1.086 (0.239). The distributions of these five variables are similar to those reported in prior literature (e.g. Khan and Watts, 2009). However, the mean Size is large, suggesting that European firms have large market value of equity. Size, Market-to-Book, and Lev variables capture firm characteristics that are widely available and commonly used, as well as four traditional explanations of accounting conservatism in prior literature ${ }^{4}$.

The rest of the four variables in Table 2 are used in information environment model. Forecast error is the absolute error divided by the closing stock price of the previous year. Mean (median) of forecast error is 0.243 (0.014). The standard deviation of forecast error is 2.648 , suggesting that analysts have quite different views

\footnotetext{
${ }^{4}$ Khan and Watts (2009) present more detailed explanations towards this argument.
} 
towards earnings per share for next period. This circumstance might be the result of unclear future economic trend. Analyst following is the natural log of the number of the number of analysts forecasting earnings per share. Mean (median) of analyst following is 50.220 (29). Forecast horizon is defined as the natural log of the number of days between the forecast's issue date and the earnings announcement date. Mean (median) of forecast horizon is 5.271 (5.285). Earnings surprise is the change in earnings per share between two years deflated by the closing stock price of the previous year. Mean (median) of earnings surprise is 0.032 (0.001). Except for Forecast error, the distribution of the rest analyst forecast variables are consistent with prior literature (Horton and Serafeim, 2010). 
Table 3: Correlation Matrix (Pearson Top; Spearman Bottom)

\begin{tabular}{|c|c|c|c|c|c|c|c|c|}
\hline & $\frac{\text { Earnings- }}{\underline{\text { Price ratio }}}$ & $\underline{\text { Size }}$ & $\underline{\mathrm{M} / \mathrm{B}}$ & $\underline{\text { Lev }}$ & $\frac{\text { Forecast }}{\underline{\text { Error }}}$ & $\frac{\text { Analyst }}{\text { Following }}$ & $\frac{\text { Forecast }}{\text { Horizon }}$ & $\begin{array}{l}\text { Earnings } \\
\underline{\text { Surprise }}\end{array}$ \\
\hline Earnings-Price ratio & 1 & $0.085^{\mathrm{a}}$ & -0.038 & $-0.048^{\mathrm{a}}$ & $-\overline{-0.030^{c}}$ & $0.034^{\mathrm{c}}$ & $-0.022^{\mathrm{c}}$ & $0.107^{\mathrm{a}}$ \\
\hline Size & $0.070^{\mathrm{a}}$ & 1 & $0.341^{\mathrm{a}}$ & $-0.045^{\mathrm{a}}$ & $-0.057^{\mathrm{a}}$ & $0.351^{\mathrm{a}}$ & $0.091^{\mathrm{a}}$ & $-0.038^{b}$ \\
\hline $\mathrm{M} / \mathrm{B}$ & $-0.102^{a}$ & $0.542^{\mathrm{a}}$ & 1 & $-0.247^{\mathrm{a}}$ & -0.018 & -0.020 & $0.069^{\mathrm{a}}$ & -0.013 \\
\hline Lev & $0.029^{\mathrm{a}}$ & $-0.097^{\mathrm{a}}$ & $-0.664^{\mathrm{a}}$ & 1 & $0.018^{c}$ & 0.014 & 0.062 & $0.025^{\mathrm{d}}$ \\
\hline Forecast Error & $-0.021^{\mathrm{a}}$ & $-0.115^{\mathrm{a}}$ & $-0.203^{\mathrm{a}}$ & $0.060^{\mathrm{a}}$ & 1 & $-0.020^{b}$ & $0.103^{\mathrm{a}}$ & $0.012^{\mathrm{b}}$ \\
\hline Analyst Following & $0.087^{\mathrm{a}}$ & $0.432^{\mathrm{a}}$ & $-0.073^{\mathrm{a}}$ & $0.037^{\mathrm{b}}$ & $-0.085^{\mathrm{a}}$ & 1 & $0.113^{\mathrm{a}}$ & 0.007 \\
\hline Forecast Horizon & $-0.086^{\mathrm{a}}$ & $0.128^{\mathrm{a}}$ & $0.102^{\mathrm{a}}$ & $-0.092^{\mathrm{a}}$ & $0.073^{\mathrm{d}}$ & $0.178^{\mathrm{a}}$ & 1 & $0.027^{\mathrm{b}}$ \\
\hline Earnings Surprise & $0.363^{\mathrm{a}}$ & $-0.045^{\mathrm{a}}$ & $0.041^{\mathrm{b}}$ & 0.019 & 0.014 & -0.007 & $0.035^{\mathrm{b}}$ & 1 \\
\hline
\end{tabular}

Table 3 shows correlations for 9,237 firm-years between 2001 and 2010. The upper (lower) right triangle of the matrix shows Pearson (Spearman) correlations. Earnings-Price ratio is calculated as earnings per share (Worldscope item \#05201) divided by price (Worldscope item \#05001). Return is the return on each firm from 9 months before fiscal year-end to three months after fiscal year-end, including dividend paid and adjusted for stock dividends and capital contributions (Datastream). Size is the natural $\log$ of market value of equity. Market value of equity is calculated as common shares outstanding (Worldscope item \#05301) times price (Worldscope item \#05001). M/B stands for the market-to-book ratio of common equity based on the closing price at year end. Lev is leverage, defined as short-term debt (Worldscope item \#03051) and long-term debt (Worldscope item \#03251) divided by market value of equity.

Forecast error is the absolute error divided by the closing stock price of the previous year. Analyst following is the natural log of the number of analysts forecasting earnings per share for a firm. Forecast horizon, earnings surprise, size, and return are control variables that might affect the analyst variables. Forecast horizon is defined as the natural log of the number of days between the forecast's issue date and the earnings announcement date. Earnings surprise is defined as the change in earnings per share between two years divided by the closing stock price of the previous year.

$\mathrm{a}, \mathrm{b}, \mathrm{c}, \mathrm{d}$ denotes two-tailed significance at $p$ inferior to $0.001,0.01,0.05$, and 0.10 , respectively. 
Table 3 shows the correlation matrix for variables used in calculating C_Score and testing information environment, over the period 2001 to 2010. The upper (lower) right triangle reports the Pearson (Spearman) correlations. Earnings-Price ratio is positively correlated with Size, but is negatively correlated with Market-to-Book ratio and Lev. The Pearson (Spearman) correlation between leverage and M/B is -0.247 (0.664), consistent with Khan and Watts (2009). Forecast error is negatively correlated with number of analyst following. Consist with the prior literature (Clement, 1999), forecast horizon is positively related to forecast error, suggesting the longer the time between forecast and actual earnings announcement, the higher forecast error. Earnings surprise exhibits a positive correlation with forecast error and a negative relationship with number of analysts following.

\section{Results}

\subsection{Accounting conservatism after IFRS adoption}

At the top of Table 4, I report the Basu coefficient of each sample. We can see that Early IFRS adopters have the highest level of accounting conservatism (Basu coefficient $=1.48, \mathrm{t}=12.49$ ). This result provide evidence that firms become less conservative after IFRS adoption, no matter early, on-time, or late adopters.

Then, I calculate C_Score, which represent the level of accounting conservatism, for each firm. To do so, I estimate the Fama-Mecbeth regression in Equation (1) annually and, then, summarize the mean coefficients over the 10 years in Table 4. After getting the coefficients, I calculate the C_Score for a firm-year as given in Equation (2), using coefficients in Table 4. 
Table 4: Mean Coefficients from Estimation Regression of Equation (1) and (3) (Dependent Variable is calculated by extracting data from Worldscope)

\begin{tabular}{lcccc}
\hline & Pooled & Early & $\underline{\text { On-time }}$ & $\underline{\text { Late }}$ \\
Basu Coefficient & $\mathbf{0 . 8 2 8 8 0}$ & $\mathbf{1 . 4 8 1 1 6}$ & $\mathbf{0 . 9 9 4 9 1}$ & $\mathbf{0 . 2 2 9 9 4}$ \\
& $(30.89)^{\mathrm{a}}$ & $(12.49)^{\mathrm{a}}$ & $(28.43)^{\mathrm{a}}$ & $(6.77)^{\mathrm{a}}$ \\
\hline & & & & \\
Intercept & $0.093(4.04)^{\mathrm{b}}$ & $-0.084(-1.46)$ & $0.060(1.98)^{\mathrm{d}}$ & $0.057(1.11)^{\mathrm{d}}$ \\
D & $0.261(2.39)^{\mathrm{c}}$ & $0.320(1.58)^{\mathrm{c}}$ & $0.252(4.26)^{\mathrm{b}}$ & $0.131(0.84)$ \\
& & & & \\
R & $0.030(2.71)^{\mathrm{c}}$ & $0.109(0.99)$ & $0.078(3.99)^{\mathrm{b}}$ & $0.038(3.49)^{\mathrm{a}}$ \\
R x Size & $0.012(4.01)^{\mathrm{a}}$ & $0.008(1.20)$ & $0.004(0.66)$ & $0.006(1.56)^{\mathrm{d}}$ \\
R x M/B $_{\text {R }}$ & $-0.003(-1.31)$ & $0.039(0.60)$ & $-0.001(-1.12)$ & $-0.002(-0.57)$ \\
R x Lev & $0.021(0.43)$ & $0.127(1.08)$ & $0.018(0.81)$ & $-0.051(-0.46)$ \\
& & & & \\
D x R & $\mathbf{2 . 7 4 7}(11.79)^{\mathrm{a}}$ & $\mathbf{1 . 5 6 6}(8.30)^{\mathrm{a}}$ & $\mathbf{3 . 1 7 4}(15.95)^{\mathrm{a}}$ & $\mathbf{0 . 5 6 2}(7.03)^{\mathrm{a}}$ \\
D x R x Size & $\mathbf{- 0 . 1 6 4}(-9.06)^{\mathrm{a}}$ & $\mathbf{- 0 . 1 0 6}(-7.53)^{\mathrm{a}}$ & $\mathbf{- 0 . 2 0 3}(-15.05)^{\mathrm{a}}$ & $\mathbf{- 0 . 0 5 7}(-1.67)^{\mathrm{d}}$ \\
D x R x M/B & $\mathbf{- 0 . 0 0 4}(-2.08)$ & $\mathbf{- 0 . 2 4 9}(-4.04)^{\mathrm{c}}$ & $\mathbf{- 0 . 0 0 1}(0.19)$ & $\mathbf{- 0 . 0 0 2}(-0.52)$ \\
D x R x Lev & $\mathbf{0 . 1 0 1}(1.94)^{\mathrm{d}}$ & $\mathbf{0 . 4 5 9}(5.20)^{\mathrm{b}}$ & $\mathbf{0 . 1 2 5}(5.80)^{\mathrm{a}}$ & $\mathbf{0 . 3 3 6}(2.35)^{\mathrm{c}}$ \\
& & & & \\
Size & $0.003(2.18)$ & $0.009(2.72)$ & $0.001(0.07)$ & $-0.003(-1.05)$ \\
M/B & $-0.038(-2.48)^{\mathrm{b}}$ & $-0.003(-0.56)$ & $-0.0013(-4.06)^{\mathrm{a}}$ & $0.003(0.10)$ \\
Lev & $0.006(0.70)$ & $-0.013(-9.25)^{\mathrm{a}}$ & $-0.009(-2.42)^{\mathrm{c}}$ & $0.089(5.20)^{\mathrm{a}}$ \\
D x Size & $-0.016(2.16)^{\mathrm{c}}$ & $-0.026(-1.44)$ & $-0.017(-2.79)^{\mathrm{b}}$ & $-0.012(-4.52)^{\mathrm{a}}$ \\
D x M/B & $0.005(1.33)^{\mathrm{a}}$ & $-0.055(-1.30)^{\mathrm{d}}$ & $0.004(0.51)$ & $-0.002(-1.97)^{\mathrm{c}}$ \\
D x Lev & $0.095(3.03)^{\mathrm{c}}$ & $0.163(1.16)$ & $0.032(1.62)^{\mathrm{d}}$ & $0.075(8.47)^{\mathrm{a}}$ \\
\hline
\end{tabular}

Number of

Observation

19,029

1901

12107

5021

C_Score

0.568519

0.951888

0.597556

0.355085

Table 4 shows mean coefficients from annual Fama-Macbeth regressions of the following model, on a sample of 19,540 firm-years from 2001 to 2010.

$$
\begin{aligned}
& X_{i, t} / P_{i, t-1}=\beta_{0}+\beta_{1} D_{i, t}+R_{i, t}\left(\mu_{0}+\mu_{1} \text { Size }_{i, t}+\mu_{2} M / B_{i, t}+\mu_{3} \operatorname{Lev}_{i, t}\right)+ \\
& D_{i, t} R_{i, t}\left(\lambda_{0}+\lambda_{1} \text { Size }_{i, t}+\lambda_{2} M / B_{i, t}+\lambda_{3} \operatorname{Lev}_{i, t}\right)+\left(\delta_{1} \text { Size }_{i, t}+\delta_{2} M / B_{i, t}+\right. \\
& \left.\delta_{3} \operatorname{Lev}_{i, t}+\delta_{4} D_{i} \text { Size }_{i, t}+\delta_{5} D_{i, t} M / B_{i, t}+\delta_{6} D_{i, t} \operatorname{Lev}_{i, t}\right)+\varepsilon_{i, t} \\
& X_{i, t} / P_{i, t-1}=\beta_{0}+\beta_{1} D_{i, t}+\beta_{2} R_{i, t}+\beta_{3} D_{i, t} R_{i, t}+\varepsilon_{i, t}
\end{aligned}
$$

$\mathrm{D}$ is a dummy variable equal to 1 if returns are negative and 0 elsewhere. Size is the natural log of market value of equity. Market value of equity is calculated as common shares outstanding (Worldscope item \#05301) times price (Worldscope item \#05001). $\mathrm{M} / \mathrm{B}$ stands for the market-to- book ratio of common equity based on the closing price 
at year end. Lev is leverage, defined as short-term debt (Worldscope item \#03051) and long-term debt (Worldscope item \#03251) divided by market value of equity calculated before.The coefficients estimates in the table are used to calculate C_Score.

Firms adopting IFRS before 2005 are regarded as early adopters; firms adopting IFRS in 2005 are regarded as on-time adopters; firms adopting IFRS after 2005 are regarded as late adopters; Firms that use accounting standards other than IFRS in 2010, such as local standards, International standards, or U.S. GAAP, are regarded as non-adopters.

T-statistics are in the brackets. $\mathrm{a}, \mathrm{b}, \mathrm{c}, \mathrm{d}$ denotes two-tailed significance at $p$ inferior to $0.001,0.01,0.05$, and 0.10 , respectively.

Table 4 shows the mean coefficients from estimation regression of Equation (1) and (3). The first column reports coefficients from full pooled sample. The rest are over several sample breakdowns according to IFRS adoption timing: Early, On-time, and Late. In both pooled and breakdown samples, earnings and returns, which are represented by coefficients of $\mathrm{R}$ and DxR, are significantly positive, suggesting both good news and bad news will be reflected in earnings. This result is consistent with that in Basu (1997). The positive coefficient of DxR indicates that firms are conservative on average. In addition, the coefficients of DxRxSize are significantly negative. Consistent with previous studies (Giner and Rees, 2001; Basu, 2001), this result means that larger firms are more likely to have lower level of accounting conservatism. The coefficients of DxRxLev are significantly positive, consistent with the idea that more levered firms have higher level of accounting conservatism (Basu et al., 2001, Ball and Shivakumar, 2005; Beaver and Ryan, 2009). However, the signs of DxRxM/B are mixed across pooled and breakdown samples. Also, the coefficients of DxRxM/B are insignificant. These results are likely due to the buffer problem which has been mentioned in previous section. The mean coefficients of DxR, DxRxSize, DxRxM/B ${ }^{5}$, and DxRxLev are used to calculate C_Score in Equation (2).

At the bottom of Table 4, I report the average C_Score of each sample. We can see that Early IFRS adopters have the highest level of accounting conservatism $\left(\mathrm{C} \_\right.$Score $\left.=0.9518\right)$. This result provides the same evidence as Basu coefficients.

\footnotetext{
${ }^{5}$ Even though the coefficient of DxRxM/B is insignificant, this result is consistent with Khan and Watts (2009).
} 
One concern of using C_Score to measure accounting conservatism is worth noting. Khan and Watts (2009) caution that C_Score may not be appropriate to proxy for accounting conservatism in countries or regions other than U.S. because of the different institutional features. Therefore, I rank the firms according to their C_Score and divide them into three groups, representing three level of accounting conservatism (low, medium, and high). Then, I run Basu (1997) returns-based asymmetric timeliness model for each group.

Table 5: Coefficients from Basu (1997) regressions by high, medium, and low C_Score groups

\begin{tabular}{lcccc}
\hline C_Score Group & Intercept & $\underline{\mathbf{D}}$ & $\underline{\mathbf{R}}$ & $\underline{\mathbf{D} \times \mathbf{R}}$ \\
G1 (Low) & 0.0275 & 0.0542 & 0.0032 & $\mathbf{0 . 0 9 1 2}$ \\
& $(10.33)$ & $(2.97)$ & $(1.16)$ & $(10.33)^{\mathrm{a}}$ \\
G2 (Medium) & 0.0602 & 0.0086 & 0.1033 & $\mathbf{0 . 2 3 0 0}$ \\
& $(1.54)$ & $(1.85)$ & $(7.57)$ & $(14.35)^{\mathrm{a}}$ \\
G3 (High) & 0.0592 & 0.1697 & 0.1608 & $\mathbf{1 . 4 4 8 3}$ \\
& $(3.96)$ & $(6.41)$ & $(8.52)$ & $(22.49)^{\mathrm{a}}$ \\
High-Low & & & & $\mathbf{1 . 3 5 7 1}$ \\
\hline
\end{tabular}

Table 5 examines the validity of C_Score in distinguishing different level of accounting conservatism by detecting the trend of coefficients in Basu (1997) model. Firms are first classified into three equal-size groups by C_Score, and, then, I estimate the following regression for each group:

Basu (1997) model: $X_{i, t} / P_{i, t-1}=\beta_{0}+\beta_{1} D_{i, t}+\beta_{2} R_{i, t}+\beta_{3} D_{i, t} R_{i, t}+\varepsilon_{i, t}$

$\mathrm{X}$ is earnings per share; $\mathrm{P}$ is year-end stock price per share. $\mathrm{X} / \mathrm{P}$ ratio here is calculated as earnings per share (Worldscope item \#05201) divided by price (Worldscope item \#05001). Return is the return on each firm from 9 months before fiscal year-end to three months after fiscal year-end, including dividend paid and adjusted for stock dividens and capital contributions (Datastream); D is a dummy variable which equals 1 if $R$ is negative and 0 elsewhere.

Table 5 examines the validity of C_Score in distinguishing different level of accounting conservatism by detecting the trend of coefficients in Basu (1997) model. The coefficients DxR increase across the three groups from $0.0912(t=10.33)$ to $1.4483(\mathrm{t}=22.49)$. This result is consistent with the trend of changing accounting conservatism ranked by C_Score. The difference between high and low C_Score 
group is 1.3571 . Consequently, the $\mathrm{C}_{-}$Score measure of accounting conservatism is effective in distinguish EU firms, because of the same trend of changing Basu coefficients.

After checking the validity of C_Score, I sort the firms by years and average the C_Score of all the firms. Also, I run Basu (1997) model of each year. Finally, it comes up with 10 averages C_Score and 10 Basu coefficients from 2001 to 2010.

Table 6: Comparison of C_Score and Basu Coefficient per year (pooled)

\begin{tabular}{|c|c|c|}
\hline Year & $\underline{\text { C__Score }}_{t}$ & $\underline{\text { Basu Coefficient }}$ \\
\hline 2001 & 0.603121 & $\begin{array}{l}1.15406 \\
(11.68)^{\mathrm{a}}\end{array}$ \\
\hline 2002 & 0.679558 & $\begin{array}{c}1.58523 \\
(8.02)^{\mathrm{a}}\end{array}$ \\
\hline 2003 & 0.481594 & $\begin{array}{l}0.93303 \\
(14.67)^{\mathrm{a}}\end{array}$ \\
\hline 2004 & 0.568708 & $\begin{array}{c}0.87609 \\
(8.10)^{\mathrm{a}}\end{array}$ \\
\hline 2005 & 0.519725 & $\begin{array}{c}\mathbf{0 . 6 9 9 9 6} \\
(3.78)^{b}\end{array}$ \\
\hline 2006 & 0.464116 & $\begin{array}{c}0.56895 \\
(7.05)^{\mathrm{a}}\end{array}$ \\
\hline 2007 & 0.446740 & $\begin{array}{c}0.61411 \\
(6.57)^{\mathrm{a}}\end{array}$ \\
\hline 2008 & 0.720247 & $\begin{array}{c}0.97395 \\
(3.50)^{b}\end{array}$ \\
\hline 2009 & 0.602386 & $\begin{array}{l}1.08375 \\
(14.73)^{\mathrm{a}}\end{array}$ \\
\hline 2010 & 0.598613 & $\begin{array}{l}1.16825 \\
(16.11)^{\mathrm{a}}\end{array}$ \\
\hline
\end{tabular}

Table 6 compares the changing trend of $\mathrm{C}$-Score and Basu Coefficient according to years. C_Score for firm i in year $t$ is calculated by taking coefficients of DxR, DxRxSize, DxRxM/B, and DxRxLev in Table 3 into the following equation.

$C_{-}$Score $_{i, t}=\lambda_{0}+\lambda_{1}$ Size $_{i, t}+\lambda_{2} M / B_{i, t}+\lambda_{4}$ Lev $_{i, t}$

Then, I group them by year and get the average of C_Score for each year which is presented in above table. Basu coefficients per year are calculated using Basu (1997) for each group. 
Table 6 compares the changing trend of Basu coefficient and C_Score according to years. From 2002 to 2005, both Basu coefficient and C_Score are decreasing. After mandatory IFRS adoption in 2005, the level of accounting conservatism of European firms continues decrease, reaching the lowest level before 2008 (Basu coefficient $=0.56895, \mathrm{t}=7.05 ;$ C_Score $=0.4467)$. However, in 2008, the conservatism climbs to the high level $($ Basu coefficient $=0.9739, \mathrm{t}=3.50 ;$ C_Score $=$ 0.7202), likely due to the global economic crisis. Firms are experiencing hard time during 2008 and it seems that they prefer conservative accounting to provide more credit on their current performance and ease the concern of debtholders. After the economic crisis, the level of accounting conservatism falls, but still higher than levels before 2008 .

Plotting the Basu coefficient and C_Score in Table 6, I get Figure 1.

Figure 1: Conservatism Plot (pooled)

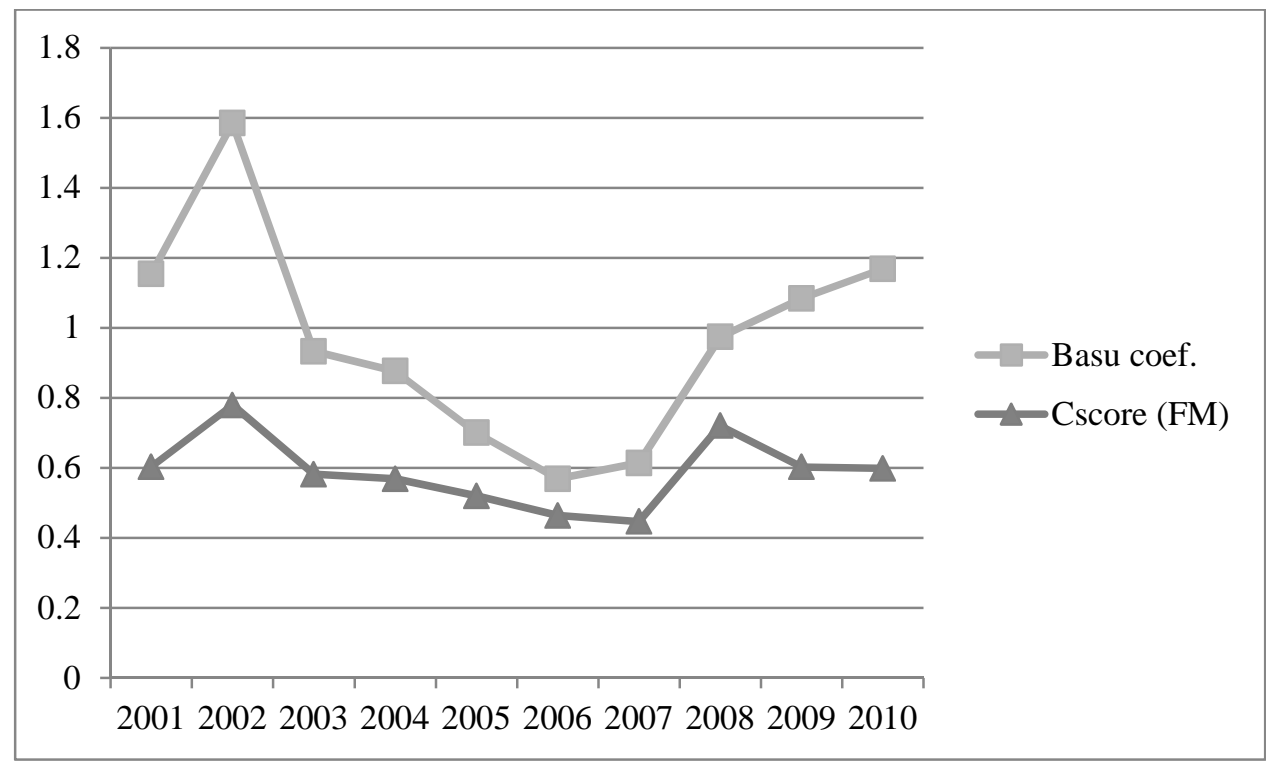

Figure 1 shows the changing of accounting conservatism which is represented by Basu coefficient and C_Score across time. Overall, the trend of C_Score is consistent with that of Basu coefficients. However, Basu coefficients are more volatile, ranging from 1.58 in year 2002 to 0.56 in year 2006. In summary, results in 
Table 6 and Figure 1 indicate that the accounting conservatism decreases after IFRS adoption, supporting hypothesis $1 \mathrm{~b}$.

Furthermore, using the coefficients in Table 7, I plot the good news versus bad news across year. The result is shown in Figure 2.

Table 7: Coefficients of Basu (1997) model across year (pooled)

\begin{tabular}{|c|c|c|c|}
\hline$\underline{\text { Year }}$ & B2(Good News) & B3 (Difference) & $\underline{\beta 2}+\beta 3(\mathrm{Bad}$ News $)$ \\
\hline 2001 & $\begin{array}{l}-0.013 \\
(-0.02)\end{array}$ & $\begin{array}{l}1.15406 \\
(11.68)^{\mathrm{a}}\end{array}$ & 1.14106 \\
\hline 2002 & $\begin{array}{c}-0.164 \\
(-3.99)^{\mathrm{a}}\end{array}$ & $\begin{array}{c}1.58523 \\
(8.02)^{\mathrm{a}}\end{array}$ & 1.42123 \\
\hline 2003 & $\begin{array}{c}0.015 \\
(2.74)^{\mathrm{a}}\end{array}$ & $\begin{array}{l}0.93303 \\
(14.67)^{\mathrm{a}}\end{array}$ & 0.94802 \\
\hline 2004 & $\begin{array}{c}0.011 \\
(4.94)^{\mathrm{a}}\end{array}$ & $\begin{array}{c}0.87609 \\
(8.10)^{\mathrm{a}}\end{array}$ & 0.88709 \\
\hline 2005 & $\begin{array}{c}0.126 \\
(3.78)^{\mathrm{a}}\end{array}$ & $\begin{array}{c}0.69996 \\
(3.78)^{b}\end{array}$ & 0.82596 \\
\hline 2006 & $\begin{array}{c}0.197 \\
(1.76)^{\mathrm{c}}\end{array}$ & $\begin{array}{c}0.56895 \\
(7.05)^{\mathrm{a}}\end{array}$ & 0.76595 \\
\hline 2007 & $\begin{array}{l}-0.028 \\
(-0.81)\end{array}$ & $\begin{array}{c}0.61411 \\
(6.57)^{\mathrm{a}}\end{array}$ & 0.58611 \\
\hline 2008 & $\begin{array}{l}0.002 \\
(0.01)\end{array}$ & $\begin{array}{c}0.97395 \\
(3.50)^{b}\end{array}$ & 0.97595 \\
\hline 2009 & $\begin{array}{l}-0.003 \\
(-0.17)\end{array}$ & $\begin{array}{l}1.08375 \\
(14.73)^{\mathrm{a}}\end{array}$ & 1.08075 \\
\hline 2010 & $\begin{array}{l}0.003 \\
(0.13)\end{array}$ & $\begin{array}{l}1.16825 \\
(16.11)^{\mathrm{a}}\end{array}$ & 1.17125 \\
\hline
\end{tabular}

Table 7 shows the coefficients of $R$ and DxR in Basu (1997) model from 2001 to 2010.

Basu (1997) model: $X_{i, t} / P_{i, t-1}=\beta_{0}+\beta_{1} D_{i, t}+\beta_{2} R_{i, t}+\beta_{3} D_{i, t} R_{i, t}+\varepsilon_{i, t}$

$\mathrm{X}$ is earnings per share; $\mathrm{P}$ is year-end stock price per share. $\mathrm{X} / \mathrm{P}$ ratio here is calculated as earnings per share (Worldscope item \#05201) divided by price (Worldscope item \#05001). Return is the return on each firm from 9 months before fiscal year-end to three months after fiscal year-end, including dividend paid and adjusted for stock dividens and capital contributions (Datastream); D is a dummy variable which equals 1 if $\mathrm{R}$ is negative and 0 elsewhere. 
Figure 2: Good news versus Bad news Plot (pooled)

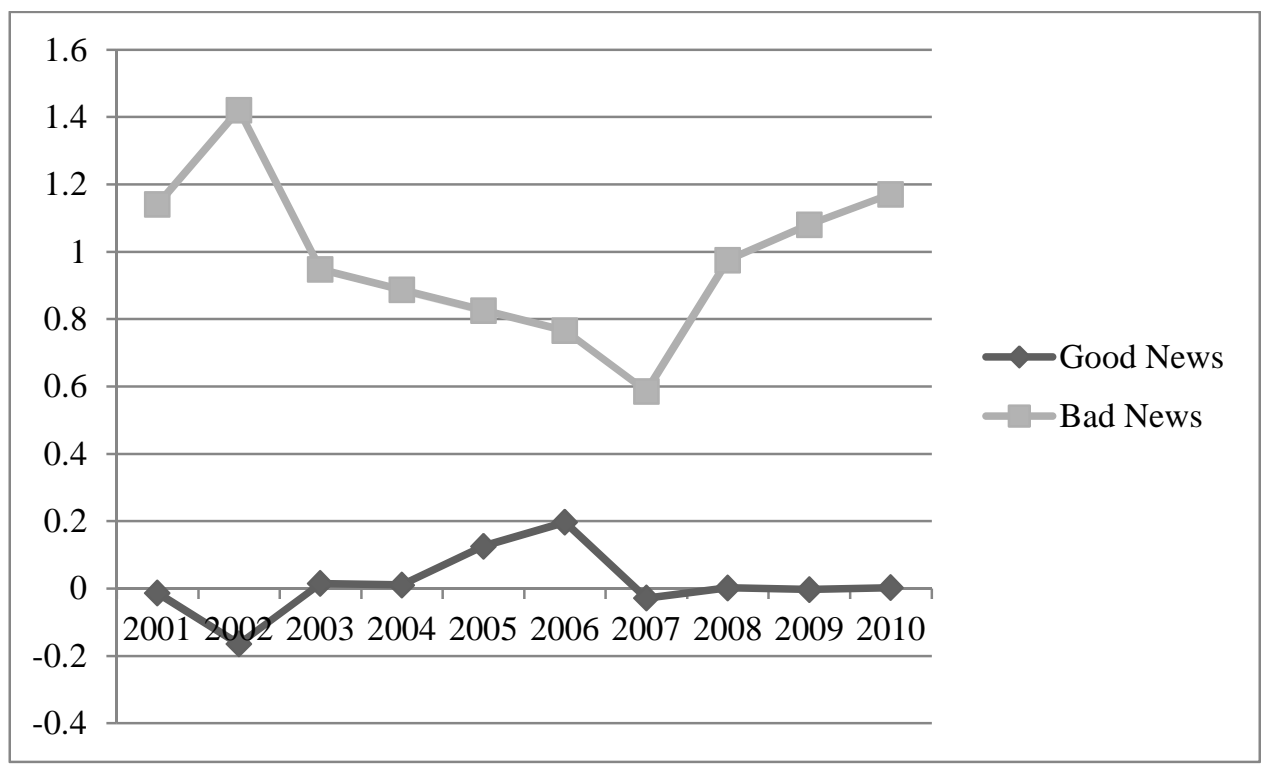

Figure 2 shows the change of good news and bad news from 2001 to 2010. Good news is represented by the coefficient of $R$, which is $\beta_{2}$ in the Basu (1997) model. Bad news is the sum of coefficients of $R$ and DxR, which is the sum of $\beta_{2}$ and $\beta_{3}$. General, the good news and bad news present an opposite trend. This indicates that if there is an increase in the earnings reflecting good news, there will be a corresponding decrease in the earnings reflecting bad news. This result is consistent with that in Basu (1997) who plot the good news against bad news from 1964 to 1989. From 2001 to 2010, there is a big difference between the coefficient on good news and bad news. However, after mandatory IFRS adoption, the difference seems to be reduced. Nevertheless, the difference enlarges again after 2008. The opposite trend between good news and bad news become vague. This might because of the insignificant coefficients of $\mathrm{R}$ in Table 7.

In addition, I compare the Basu coefficient for three subsamples: early, on-time, and late IFRS adopters. Table 8 shows the Basu coefficients for each group across year. 
Table 8: Basu coefficients for Early, On-time, and Late IFRS adopters

\begin{tabular}{cccc}
\hline Year & $\underline{\text { Early }}$ & $\underline{\text { On-time }}$ & $\underline{\text { Late }}$ \\
2001 & 0.7324 & 0.5855 & 0.2538 \\
& $(4.15)^{\mathrm{a}}$ & $(6.73)^{\mathrm{a}}$ & $(4.83)^{\mathrm{a}}$ \\
2002 & 3.6944 & 1.0831 & 0.1399 \\
& $(3.76)^{\mathrm{b}}$ & $(7.85)^{\mathrm{a}}$ & $(1.03)$ \\
2003 & 0.8010 & 0.9883 & 0.9168 \\
& $(4.11)^{\mathrm{a}}$ & $(11.19)^{\mathrm{a}}$ & $(9.99)^{\mathrm{a}}$ \\
2004 & 2.888 & 0.7389 & 0.5859 \\
& $(3.82)^{\mathrm{b}}$ & $(7.46)^{\mathrm{a}}$ & $(3.12)^{\mathrm{b}}$ \\
2005 & 1.1994 & 0.6364 & 0.0429 \\
& $(6.56)^{\mathrm{a}}$ & $(4.81)^{\mathrm{a}}$ & $(0.75)$ \\
2006 & 0.3995 & 1.0366 & 0.1309 \\
& $(1.66)$ & $(9.30)^{\mathrm{a}}$ & $(2.24)^{\mathrm{d}}$ \\
2007 & 0.3609 & 0.9149 & 0.1813 \\
& $(2.78)^{\mathrm{c}}$ & $(15.53)^{\mathrm{a}}$ & $(0.6)$ \\
2008 & 0.8479 & 1.3009 & 0.2288 \\
& $(1.07)$ & $(1.47)$ & $(1.74)$ \\
2009 & 1.5007 & 1.2778 & 0.5290 \\
& $(6.55)^{\mathrm{a}}$ & $(12.59)^{\mathrm{a}}$ & $(5.27)^{\mathrm{a}}$ \\
2010 & 0.4292 & 2.1042 & 0.0107 \\
& $(1.47)$ & $(15.91)^{\mathrm{a}}$ & $(0.14)$ \\
\hline
\end{tabular}

Table 8 shows the coefficient of DxR in Basu (1997) model from 2001 to 2010.

Basu (1997) model: $X_{i, t} / P_{i, t-1}=\beta_{0}+\beta_{1} D_{i, t}+\beta_{2} R_{i, t}+\beta_{3} D_{i, t} R_{i, t}+\varepsilon_{i, t}$

$\mathrm{X}$ is earnings per share; $\mathrm{P}$ is year-end stock price per share. $\mathrm{X} / \mathrm{P}$ ratio here is calculated as earnings per share (Worldscope item \#05201) divided by price (Worldscope item \#05001). Return is the return on each firm from 9 months before fiscal year-end to three months after fiscal year-end, including dividend paid and adjusted for stock dividens and capital contributions (Datastream); D is a dummy variable which equals 1 if $R$ is negative and 0 elsewhere.

Figure 3 shows the conservatism plot measured by Basu coefficient of early, on-time, and late IFRS adopters. The level of accounting conservatism for early IFRS adopters changes sharply before 2005, from 0.7324 in 2001 to 3.6944 in 2002, then, back to 0.8010 in 2003. The level of accounting conservatism of on-time IFRS adopters remains in a relatively low level and fluctuate between 0.5 to 1.5. Late IFRS adopters have the lowest the level of accounting conservatism among three groups. 
Figure 3: Conservatism Plot of Early, On-time, and Late IFRS adopters

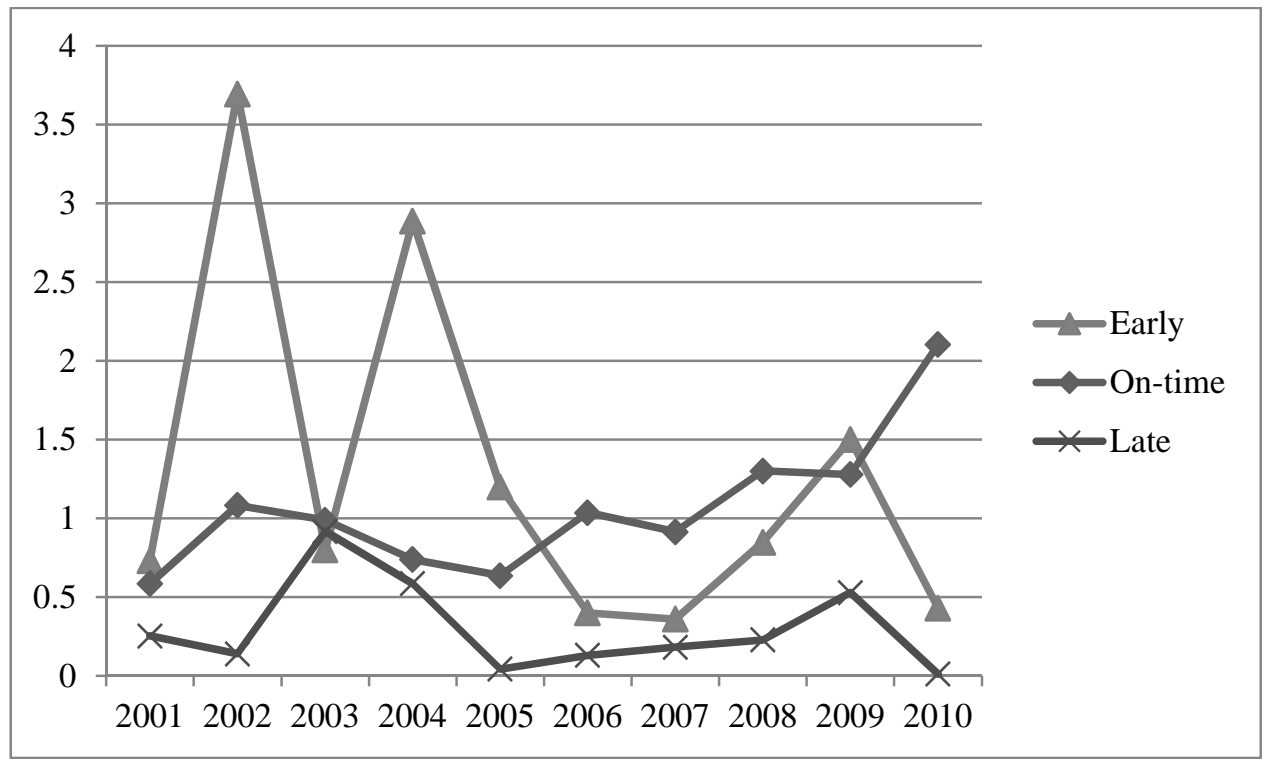

7.2 Accounting conservatism and Information asymmetry

Table 9: Mean Coefficients from Estimation Regression of Equation (4) and (5) (Dependent Variable is calculated by extracting data from Worldscope)

\begin{tabular}{lcc}
\hline & Equation (4) & $\underline{\text { Equation (5) }}$ \\
Intercept & $0.057(2.08)^{\mathrm{c}}$ & $-0.181(0.19)$ \\
$\mathrm{D}$ & $0.143(1.97)$ & $-1.418(-3.69)^{\mathrm{a}}$ \\
$\mathrm{R}$ & $0.259(4.31)^{\mathrm{b}}$ & $0.104(1.63)^{\mathrm{d}}$ \\
$\mathrm{D} \times \mathrm{R}$ & $0.503(6.56)^{\mathrm{a}}$ & $0.752(1.11)$ \\
& & \\
$\mathrm{B} / \mathrm{A}$ & $-0.015(-1.74)$ & $-0.472(-0.95)$ \\
$\mathrm{B} / \mathrm{A} \times \mathrm{D}$ & $-0.056(-0.74)$ & $1.036(1.92)^{\mathrm{c}}$ \\
$\mathrm{B} / \mathrm{A} \times \mathrm{R}$ & $0.211(2.34)^{\mathrm{c}}$ & $0.423(7.05)^{\mathrm{a}}$ \\
$\mathrm{B} / \mathrm{A} \times \mathrm{D} \times \mathrm{R}$ & $\mathbf{0 . 3 9 7}(9.45)^{\mathrm{a}}$ & $\mathbf{0 . 8 8 6}(8.32)^{\mathrm{a}}$ \\
& & \\
IFRS & & $-0.139(-1.76)$ \\
IFRS x D & & $1.556(4.33)^{\mathrm{a}}$ \\
IFRS x R & & $-0.821(-2.82)^{\mathrm{c}}$ \\
IFRS x D x R & & $0.661(1.12)^{\mathrm{d}}$ \\
IFRS x B/A & & $0.473(1.38)^{\mathrm{d}}$ \\
IFRS x B/A x D & & $-0.725(-1.40)$ \\
IFRS x B/A x R & & $-0.403(-1.96)^{\mathrm{d}}$ \\
IFRS x B/A x D x R & & $\mathbf{- 0 . 8 4 0}(-5.21)^{\mathrm{a}}$ \\
\hline
\end{tabular}


Table 7 shows mean coefficients from annual Fama-Macbeth regressions of the following model, on a sample of 6,665 firm-years from 2001 to 2010.

$$
\begin{aligned}
& X_{i, t} / P_{i, t-1}=\beta_{0}+\beta_{1} D_{i, t}+\beta_{2} R_{i, t}+\beta_{3} D_{i, t} R_{i, t}+\beta_{4} \text { Bid } / \text { Ask }_{i, t}+\beta_{5} \text { Bid } / \text { Ask }_{i, t} D D_{i, t} \\
& +\beta_{6} \text { Bid } / \text { Ask }_{i, t} R_{i, t}+\beta_{7} \text { Bid } / \text { Ask }_{i, t} D_{i, t} R_{i, t}+\varepsilon_{i, t}
\end{aligned}
$$

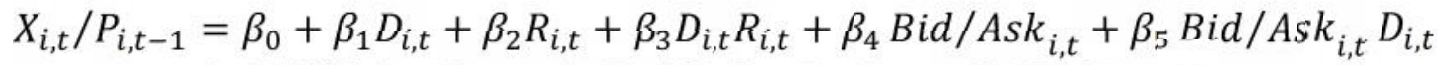

$$
\begin{aligned}
& +\beta_{6} \text { Bid } / A s k_{i, t} R_{i, t}+\beta_{7} \text { Bid/Ask }{ }_{i, t} D_{i, t} R_{i, t}+\beta_{8} I F R S_{i, t}+\beta_{9} I F R S_{i, t} D_{i, t}+
\end{aligned}
$$

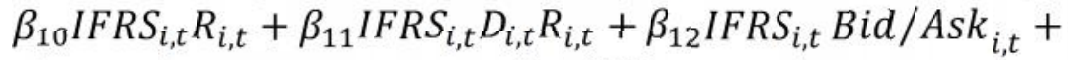

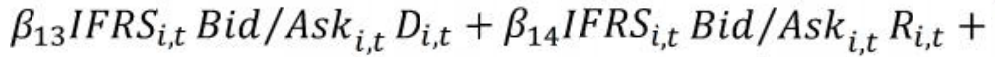

$$
\begin{aligned}
& \beta_{15} \text { IFRS }_{i, t} \text { Bid/Ask } k_{i, t} D_{i, t} R_{i, t}+\varepsilon_{i, t}
\end{aligned}
$$

Bid-ask spread is the average of the daily spread as the difference between bid price and ask price for that firm-year and, then, scaled by the midpoint of the spread. Other variables are same as before.

Table 7 shows mean coefficients from estimation regression of Equation (4) and (5). The results show that the relationship between accounting conservatism and information asymmetry is significantly positive, consistent with LaFond and Watts (2008). The coefficient of IFRSxB/AxDxR is negative (-0.840), while the coefficient of $\mathrm{B} / \mathrm{AxDxR}$ is positive (0.886). This result indicates that the adoption of IFRS will weaken the relationship between information asymmetry and conservatism. This means people might turn to other information sources to make up for the loss of accounting credibility, threatening the role of accounting as an information source. Therefore, blindly lowering the level of accounting conservatism might not weaken the role of accounting. Consistent with Basu (1997), the coefficients of R and DxR are positive. However, the coefficient of DxR in Equation (5) is not significant. It is probably because other interactive variables with DxR soak up the effect of DxR. 
7.3 Accounting conservatism and Information Environment

Table 10: Mean Coefficients from Estimation Regression of Equation (6) (Dependent Variable is calculated by extracting data from IBES)

\begin{tabular}{lcccc}
\hline & \multicolumn{3}{c}{ Forecast Error } & \multicolumn{2}{c}{ Number of Analysts } \\
Indep. Variable & Coeff. & t-stat & Coeff. & t-stat \\
Intercept & 0.923 & $(5.11)^{\mathrm{a}}$ & -2.134 & $(-10.93)^{\mathrm{a}}$ \\
& & & & \\
C_Score & $\mathbf{0 . 0 6 4}$ & $(1.22)$ & $\mathbf{1 . 9 1 0}$ & $(9.87)^{\mathrm{a}}$ \\
& & & & \\
Forecast Horizon & 0.134 & $(12.78)^{\mathrm{a}}$ & 0.036 & $(8.39)^{\mathrm{a}}$ \\
Earnings Surprise & 0.438 & $(3.21)^{\mathrm{b}}$ & 1.352 & $(1.68)^{\mathrm{d}}$ \\
Size & -0.197 & $(-9.02)^{\mathrm{a}}$ & 5.812 & $(20.43)^{\mathrm{a}}$ \\
Return & -0.516 & $(-4.55)^{\mathrm{a}}$ & -5.933 & $(-7.88)^{\mathrm{a}}$ \\
\hline
\end{tabular}

Table 8 shows mean coefficients from OLS regressions of the following model, on a sample of 9,237 firm-years from 2001 to 2010. The data used to calculate C_Score is extracted from Worldscope and Datastream. Other data for analysts' information environment is from IBES.

$$
\begin{aligned}
I E_{i, t}= & \gamma_{0}+\gamma_{1} C_{-} \text {Score }_{i, t}+\gamma_{2} \text { Forecast Horizon }_{i, t}+\gamma_{3} \text { Earnings Surprise }_{i, t}+ \\
& \gamma_{4} \text { Size }_{i, t}+\gamma_{5} \text { Return }_{i, t}+\varepsilon_{i, t}
\end{aligned}
$$

$\mathrm{IE}_{\mathrm{i}, \mathrm{t}}$ is either forecast error or analyst following. The definition of these variables follows Horton and Serafeim (2010). Forecast error is the absolute error divided by the closing stock price of the previous year. Analyst following is the natural log of the number of analysts forecasting earnings per share for a firm. Forecast horizon, earnings surprise, size, and return are control variables that might affect the analyst variables. Forecast horizon is defined as the natural $\log$ of the number of days between the forecast's issue date and the earnings announcement date. Earnings surprise is defined as the change in earnings per share between two years divided by the closing stock price of the previous year. Size is the natural log of market value of equity. Return is the return on each firm from 9 months before fiscal year-end to three months after fiscal year-end, including dividend paid and adjusted for stock dividends and capital contributions.

Table 8 shows mean coefficients from estimation regression of Equation (6). The relationship between C_Score and forecast error is insignificant, even though 
they are positive. This result indicates that there is only negligible effect of lowering accounting conservatism in order to increase forecast accuracy and information environment, supporting the argument that trying to reduce information asymmetry by decreasing the level of accounting conservatism might not be achieved, because it is information asymmetry leads to accounting conservatism. The relationship between C_Score and the number of analysts following is significantly positive (C_Score = $1.910, t=9.87$ ), suggesting that the higher level of accounting conservatism, the more analysts following. This result supports the argument that conservative accounting can provide hard information on firms' current performance for uninformed investors and also serve as benchmark for other soft information, such as management. Therefore, firms with higher level of accounting conservatism attract more analysts, because analysts believe their information is more credible. Consequently, even though accounting cannot solve the problem of reducing information asymmetry by providing unverifiable information, conservative accounting increases information environment by providing comparatively credible information.

The rest are control variables. The coefficients of forecast horizon are significantly positive for both forecast error and the number of analyst following, consist with argument that the longer the time between forecast and actual announcement, the higher forecast error and more analysts following. Earnings surprise is positively correlated with forecast error and the number of analysts. Size is negatively related with forecast error, but positively related with the number of analysts, consist with the idea that larger firms have better information environments. Return is negatively associated with forecast error and the number of analyst followings. All these four control variables are consistent with results in prior study (e.g., Horton and Serafeim, 2010).

\section{Conclusions}

This study investigates how accounting conservatism changes after mandatory IFRS adoption. Accounting conservatism will decrease if investors expect higher financial reporting quality after mandatory IFRS adoption, more financial reporting 
transparency, and lower information asymmetry. However, accounting conservatism will increase if investors expect accounting numbers to be less verifiable and turn to other information sources. In order to maintain the financial reporting as a role of information source, firms will tend to enhance the level of accounting conservatism and, thus, increasing credibility of financial reports. The empirical findings of this study shows that the level of accounting conservatism decreases after mandatory IFRS adoption and reached the lowest point before 2008. However, in 2008, accounting conservatism sharply increased, likely due to the global economic crisis. This supports the idea that the enhancement of accounting conservatism is an efficient mechanism to increase information credibility, even though investors expect higher reporting quality after mandatory IFRS adoption.

Moreover, this study shows that information asymmetry is positively related to accounting conservatism, consist with LaFond and Watts (2008), and the adoption of IFRS will weaken the relationship between them. People would turn to other information sources after the adoption of IFRS which is a allegedly principle-based accounting standard. This might be because IFRS lowers the level of accounting conservatism and, therefore, lower the credibility of accounting, threatening the role of accounting as an information source. Consequently, it is better to maintain accounting conservatism to some level instead of blindly lowering it (Ball, 2006; Watts, 2003; Basu and Waymire, 2010).

Finally, this study examines the relationship between accounting conservatism and information environment, since LaFond and Watts (2008) argue that the higher level of accounting conservatism can generate a more informed capital market. Consistent with their argument, this study shows that conservative accounting increases information environment by providing comparatively credible information, because there is a significant positive relationship between conservatism and analysts following. Moreover, empirical findings also support the implications in LaFond and Watts (2008) paper that there is only negligible effect when trying to reduce forecast error by lowering the level of accounting conservatism. 


\section{References}

Agoglia, C. P., T. S. Doupnik, and G. T. Tsakumis. 2011. Principles-based versus rules-based accounting standards: the influence of standard precision and audit committee strength on financial reporting decisions. The Accounting Review 86: 747-767.

Aharony, J., R. Barniv, and H. Falk. 2010. The impact of mandatory IFRS adoption on equity valuation of accounting numbers for security investors in the EU. European Accounting Review 19: 535-578.

Ahmed, A. S., B. K. Billings, and R. M. Morton. 2002. The role of accounting conservatism in mitigating bondholder-shareholder conflicts over dividend policy and in reducing debt costs. Accounting Review 77: 867-890.

Ahmed, A. S., M. Neel, and D. Wang. 2010. Does mandatory adoption of IFRS improve accounting quality? Preliminary evidence. Working paper.

Amihud, Y., and H. Mendelson. 1986. Asset pricing and the bid-ask spread. Journal of Financial Economics 17: 223-249.

Armstrong, C. S., M. E. Barth, A. D. Jagolinzer, and E. J. Riedl. 2010. Market reaction to the adoption of IFRS in Europe. The Accounting Review 85: 31-61.

Andre, P., and A. Filip. 2012. Accounting Conservatism in Europe and the Impact of Mandatory IFRS Adoption: Do Country, Institutional and Legal Differences Survive? Available at SSRN: http://ssrn.com/abstract=1979748 or http://dx.doi.org/10.2139/ssrn.1979748

Ashbaugh, H., and M. Pincus. 2001. Domestic accounting standards, international accounting standards, and the predictability of earnings. Journal of Accounting Research 39: 417-434.

Ball. R., 1989. The firm as a specialist contracting intermediary: Application to accounting and auditing. Working Paper, University of Rochester.

Ball, R., S. Kothari, and A. Robin. 2000. The effect of international institutional factors on properties of accounting earnings. Journal of Accounting and Economics 29: 1-51.

Ball, R., A. Robin, and J. Wu. 2003. Incentives versus standards: Properties of accounting income for four East Asian countries. Journal of Accounting and Economics 36: 235-270.

Ball, R., and L. Shivakumar. 2005. Earnings quality in UK private firms: comparative loss recognition timeliness. Journal of Accounting and Economics 39: 83-128.

Ball, R., and L. Shivakumar. 2006. The role of accruals in asymmetrically timely gain and loss recognition. Journal of Accounting Research 44: 207-242. 
Ball, R. 2006. International Financial Reporting Standards (IFRS): Pros and Cons for investors. Accounting and Business Research 36: 5-27.

Basu, S. 1997. The conservatism principle and the asymmetric timeliness of earnings. Journal of Accounting and Economics 24: 3-37.

Basu, S. 1999. Discussion of international differences in timeliness, conservatism and classification of earnings. Journal of Accounting Research 37: 89-99.

Basu, S. 2001. Discussion of on the asymmetric recognition of good and bad news in France, Germany and the United Kingdom. Journal of Business Finance and Accounting 28: 1333-1349.

Basu, S., L. S. Hwang, and C. L. Jan. 2001. Differences in conservatism between Big Eight and non-Big Eight auditors. Working paper.

Basu, S., and G. B. Waymire. 2010. Sprouse's what-you-may-call-it: Fundamental insight or monumental mistake? Accounting Historians Journal 37: 121-148.

Beatty, A., J. Weber, and J. J. Yu. 2008. Conservatism and debt. Journal of Accounting and Economics 45: 154-174.

Beaver, W. H., and S. G. Ryan. 2000. Biases and lags in book value and their effects on the ability of the book-to-market ratio to predict book return on equity. Journal of Accounting Research 38: 127-148.

Beaver, W. H., and S. G. Ryan. 2005. Conditional and unconditional conservatism: Concepts and Modeling. Review of Accounting Studies 10: 269-309.

Beaver, W. H., and S. G. Ryan. 2009. Risky debt, mixed-attribute accounting, and the identification of conditional conservatism. Working paper.

Brochet, F., A. D. Jagolinzer, and E. J. Riedl. 2011. Mandatory IFRS adoption and financial statement comparability. Working paper.

Burgstahler, D., and I. Dichev. 1997. Earnings management to avoid earnings decreases and losses. Journal of Accounting and Economics 24: 99-126.

Byard, D., Y. Li, and Y. Yu. 2011. The effect of mandatory IFRS adoption on financial analysts' information environment. Journal of Accounting Research 49: 69-96.

Callen, J. L., and M. Morel. 2000. A lintnerian linear accounting valuation model. Journal of Accounting, Auditing, and Finance 2: 301-314.

Cano-Rodriguez, M. 2010. Big auditors, private firms and accounting conservatism: Spanish evidence. European Accounting Review 19: 131-159.

Chen, J. Z., G. J. Lobo, Y. Wang, and L. Yu. 2011. Loan collateral and accounting conservatism. Working paper. 
Cheong, F. S., and J. Thomas. 2011. Why do EPS forecast error and dispersion not vary with scale? Implications for analyst and managerial behavior. Journal of Accounting Research 49: 359-401.

Christensen, H. B., E. Lee, and M. Walker. 2009. Do IFRS reconciliations convey information? The effect of debt contracting. Journal of Accounting Research 47: 1167-1199.

Chung, H. H., and J. P. Wynn. 2008. Managerial legal liability coverage and earnings conservatism. Journal of Accounting and Economics 46: 135-153.

Collins, D., and S., Kothari. 1989. An analysis of the cross-sectional and intertemporal determinants of earnings response coefficients. Journal of Accounting and Economics 11: 143-181.

Core, J. E., and C. M. Schrand. 1999. The effect of accounting-based debt covenants on equity valuation. Journal of Accounting and Economics 27: 1-34.

Dargenidou, C., and S. McLeay. 2010. The impact of introducing estimates of the future on international comparability in earnings expectations. European Accounting Review 19: 511-534.

Daske, H., L. Hail, and C. Leuz. 2008. Mandatory IFRS reporting around the world: early evidence on the economic consequences. Journal of Accounting Research 46: $1085-1142$.

Dechow, P., A. Hutton, and R. Sloan. 1999. An empirical assessment of residual income valuation model. Journal of Accounting and Economics 26: 1-34.

Dietrich, J. R., K.A. Muller, and E. J. Riedl. 2007. Asymmetric timeliness tests of accounting conservatism. Review of Accounting Studies 12: 95-142.

Dye, R. A., and S. Sunder. 2001. Why not allow FASB and IASB standards to compete in the U.S.?. Accounting Horizons 15: 257-271.

Fama, E. F., and J. MacBeth. 1973. Risk return and equilibrium: Empirical tests. Journal of Political Economy 71: 607-636.

Feltham, G. A., and J. A. Ohlson. 1995. Valuation and clean surplus accounting for operating and financial activities. Contemporary Accounting Research 11: 689731.

Fischer, P. E., and R. E. Verrecchia. 2000. Reporting Bias. The Accounting Review 75: 229-245.

Francis, J., and X. Martin. 2010. Acquisition profitability and timely loss recognition. Journal of Accounting and Economics 49: 179-183.

Garcia, L., B. G. Osma, and F. Penvalva. 2011. Conditional Conservatism and cost of capital. Review of Accounting Studies 16: 247-271. 
Gebhardt, W. R., C. Lee, and B. Swaminathan. 2001. Toward an implied cost of capital. Journal of Accounting Research 39:135-176.

Gebhardt, G. G., and Z. Novotny-Farkas. 2011. Mandatory IFRS adoption and accounting quality of European banks. Journal of Business Finance and Accounting 38: 289-333.

Gigler, F., and T. Hemmer. 2001. Conservatism, optimal disclosure policy and the timeliness of financial reports. The Accounting Review 76: 471-494.

Gigler, F., C. Kanodia, and H. Sapra. 2009. Accounting conservatism and the efficiency of debt contracts. Journal of Accounting Research 47: 767-797.

Giner, B., and W. P. Rees. 2001. The asymmetric recognition of good and bad news in France, Germany and the U.K. Journal of Business Finance and Accounting 28: $1285-1331$.

Givoly, D., and C. Hayn. 2000. The changing time-series properties of earnings, cash flows and accruals: Has financial reporting become more conservative? Journal of Accounting and Economics 29: 287-320.

Givoly, D., C. Hayn, and A. Natarajan. 2007. Measuring reporting conservatism. The Accounting Review 82: 65-106.

Gow, I. D., G. Ormazabal, and D. J. Taylor. 2010. Correcting for cross-sectional and time-series dependence in accounting research. The Accounting Review 85: 483-512.

Hail, L., C. Leuz, and P. Wysocki. 2010. Global accounting convergence and the potential adoption of IFRS by the U.S. (Part I): Conceptual underpinnings and Economic analysis. Accounting Horizons 24: 355-394.

Hanna, J.D. 2003. Conservatism and accounting measurement. Working paper, University of Chicago.

Hayn, C. 1995. The information content of losses. Journal of Accounting and Economics 20: 125-153

Healy, P., A. Hutton, and K. Palepu. 1999. Stock performance and intermediation changes surrounding sustained increases in disclosure. Contemporary Accounting Research 16: 485-520.

Holthausen, R. W., and R. Watts. 2001. The relevance of the value relevance literature for financial accounting standard setting. Journal of Accounting and Economics 31: 3-76.

Horton, J., G. Serafeim, and I. Serafeim. 2010. Does mandatory IFRS adoption improve the information environment? Working paper. 
Houston, J. F., B. Lev, and J. W. Tucker. 2008. To guide or not to guide? Causes and consequences of stopping quarterly earnings guidance. Contemporary Accounting Research 27: 143-185.

Hu, J., and F. Zhang. 2011. Does accounting conservatism improve the information environment? American Accounting Association Annual Meeting conference paper.

Jeanjean, T., and H. Stolowy. 2008. Do accounting standards matter? An exploratory analysis of earnings management before and after IFRS adoption. Journal of Accounting and Public Policy 27: 480-494.

Jin, L., and Myers, S. C. 2006. R2 around the world: New theory and new tests. Journal of Financial Economics 79: 257-292.

Kellogg, R. 1984. Accounting activities, security prices and class action lawsuits. Journal of Accounting and Economics 6: 185-204.

Khan, M., and R. L. Watts. 2009. Estimation and empirical properties of a firm-year measure of accounting conservatism. Journal of accounting and Economics 48: 132-150.

Khan, U. 2010. Does fair value accounting contribute to systemic risk in the banking industry? Working paper.

Kothari, S. P., A. J. Leone, and C. E. Wasley. 2005. Performance matched discretionary accrual measures. Journal of Accounting and Economics 39: 163197

LaFond, R., and R. L. Watts. 2008. The information role of conservatism. The Accounting Review 83: 447-478.

LaFond, R., and S. Roychowdhury. 2008. Managerial ownership and accounting conservatism. Journal of Accounting Research 46: 101-135.

Lai, C., and S. L. Taylor. 2008. Estimating and validating a firm-year-specific measure of conservatism: Australian evidence. Accounting and Finance 48: 673-695.

Lang, M., and R. Lundholm. 1996. Corporate disclosure policy and analysts behavior. The Accounting Review 71: 467-469.

Lang, M., K. Lins, and D. Miller. 2003. ADRs, analysts, and accuracy: Does cross listing in the U.S. improve a firm's information environment and increase market value? Journal of Accounting Research 41: 317-345.

Laux, C., and C. Leuz. 2009. The crisis of fair-value accounting: making sense of the recent debate. Accounting Organizations and Society 34: 826-834. 
Leuz, C., and R. Verrecchia. 2000. The economic consequences of increased disclosure. Journal of Accounting Research 38: 91-124.

Li, S. Q. 2010. Does mandatory adoption of international financial reporting standards in the European Union reduce the cost of equity capital? The Accounting Review 85: 607-636.

Lo, K., and T. Lys. 2000. The Ohlson model, contribution to valuation theory, limitations, and empirical applications. Journal of Accounting, Auditing and Finance 15: 337-367.

Nikolaev, V. V. 2010. Debt covenants and accounting conservatism. Journal of Accounting Research 48: 137-175.

Penman, S. H., and X. J. Zhang. 2002. Accounting conservatism, the quality of earnings, and stock returns. The Accounting Review 77: 237-264.

Petersen, M. A. 2009. Estimating standard errors in finance panel data sets: comparing approaches. Review of Financial Studies 22: 435-480.

Piot, C., P. Dumontier, and R. Janin. 2010. IFRS consequences on accounting conservatism within Europe. Working paper.

Plummer, C. E., and S. Y. Tse. 1999. The effect of limited liability on the informativeness of earnings: Evidence from the stock and bond markets. Contemporary Accounting Research 16: 541-574.

Pope, P., and M. Walker. 1999. International differences in timeliness, conservatism and classification of earnings. Journal of Accounting Research 37: 53-87.

Qiang, X. 2007. The effects of contracting, litigation, regulation, and tax costs on conditional and unconditional conservatism: cross-sectional evidence at the firm level. The Accounting Review 83: 759-796.

Reis, R., and P. C. Stocken. 2007. Strategic consequences of historical cost and fair value measurements. Contemporary Accounting Research 24: 557-584.

Roychowdhury, S., and R. L. Watts. 2007. Asymmetric timeliness of earnings, market-to-book and conservatism in financial reporting. Journal of Accounting and Economics 44: 2-31.

Ryan, S. G. 2006. Identifying conditional conservatism. European Accounting Review 15: 511-525.

St. Pierre, K., and J. Anderson. 1984. An analysis of the factors associated with lawsuits against public accountants. The Accounting Review 59: 242-263.

Soderstrom, N. S., and K. J. Sun. 2007. IFRS adoption and accounting quality: a review. European Accounting Review 16: 675-702. 
Wang, X., G. Young, and Z. Zhuang. 2007. The effects of mandatory adoption of International Financial Reporting Standards on information environments. American Accounting Association Conference paper.

Wang, R. Z., C. O. hOgartaigh, and T. Zijl. 2009. Measures of accounting conservatism: A construct validity perspective. Journal of Accounting Literature 28: 165-203.

Wang, S. H., and M. Welker. 2011. Timing equity issuance in response to information asymmetry arising from IFRS adoption in Australia and Europe. Journal of Accounting Research 49: 257-307.

Watts, R. L., and J. L. Zimmerman. 1986. Positive accounting theory. Prentice-Hall, Englewood Cliffs, NJ.

Watts, R. L. 2003. Conservatism in accounting part I: explanations and implications. Accounting Horizons 17: 207-221.

Watts, R. L. 2006. What has the invisible hand achieved? Accounting and Business Research 36: 51-61.

Welker, M. 1995. Disclosure policy, information asymmetry, and liquidity in equity markets. Contemporary Accounting Research 11:801-827.

Zhang, J. 2008. The contracting benefits of accounting conservatism to lenders and borrowers. Journal of Accounting and Economics 45: 27-5.

Zhang, X. 2000. Conservative accounting and equity valuation. Journal of Accounting and Economics 29: 125-149. 